\title{
Intertonguing of the Lower Part of the Uinta Formation with the Upper Part of the Green River Formation in the Piceance Creek Basin During the Late Stages of Lake Uinta
}

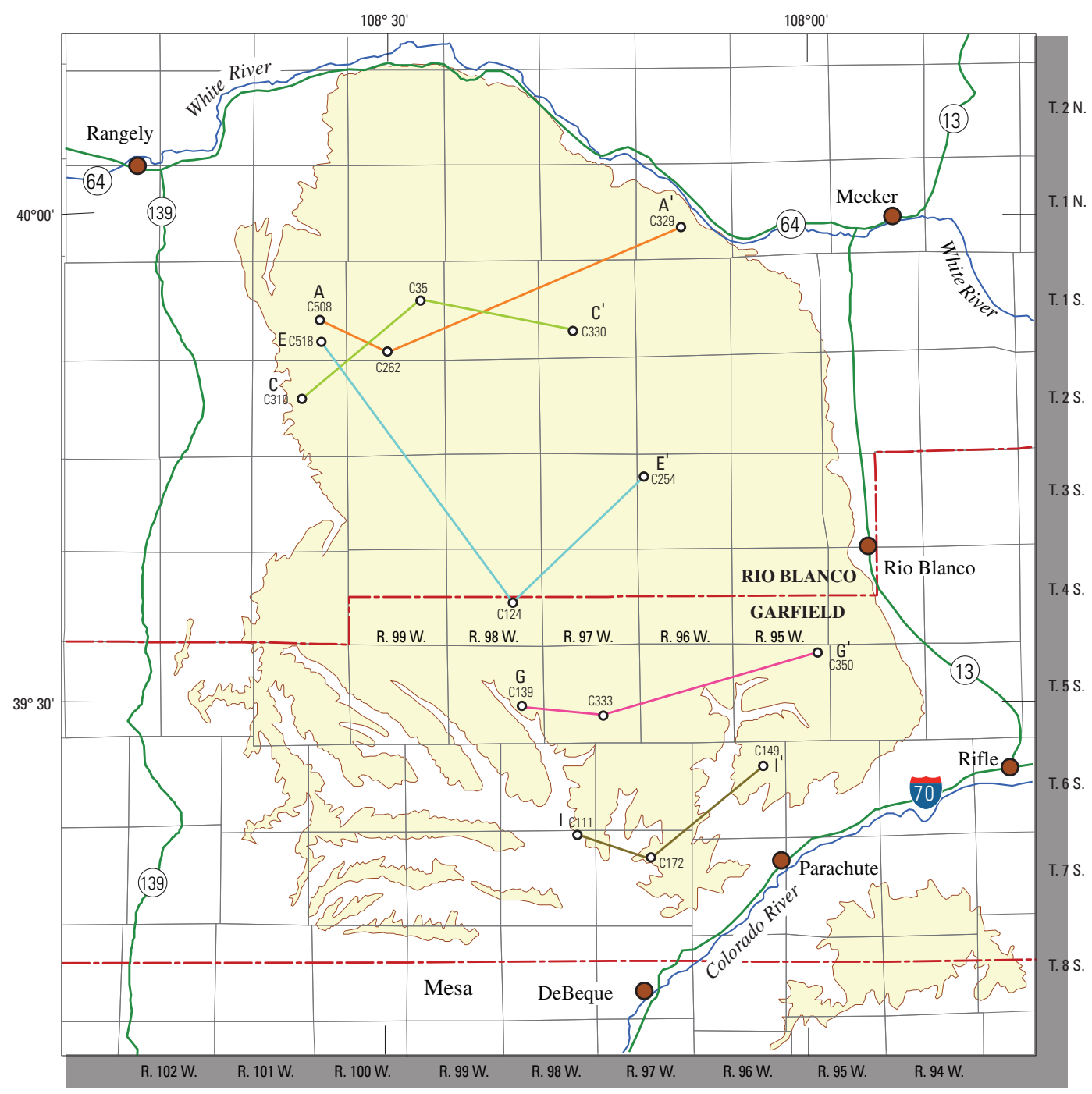

Scientific Investigations Report 2008-5237 



\section{Intertonguing of the Lower Part of the Uinta Formation with the Upper Part of the Green River Formation in the Piceance Creek Basin During the Late Stages of Lake Uinta}

By John R. Donnell

Scientific Investigations Report 2008-5237 


\title{
U.S. Department of the Interior \\ KEN SALAZAR, Secretary
}

\author{
U.S. Geological Survey \\ Suzette M. Kimball, Acting Director
}

U.S. Geological Survey, Reston, Virginia: 2009

For product and ordering information:

World Wide Web: http://www.usgs.gov/pubprod

Telephone: 1-888-ASK-USGS

For more information on the USGS - the Federal source for science about the Earth, its natural and living resources, natural hazards, and the environment:

World Wide Web: http://www.usgs.gov

Telephone: 1-888-ASK-USGS

Any use of trade, product, or firm names is for descriptive purposes only and does not imply endorsement by the U.S. Government.

Although this report is in the public domain, permission must be secured from the individual copyright owners to reproduce any copyrighted materials contained within this report.

Suggested citation:

Donnell, J.R., 2009, Intertonguing of the lower part of the Uinta Formation with the upper part of the Green River Formation in the Piceance Creek Basin during the late stages of Lake Uinta: U.S. Geological Survey, Scientific Investigations Report 2008-5237, 25 p. 


\section{Contents}

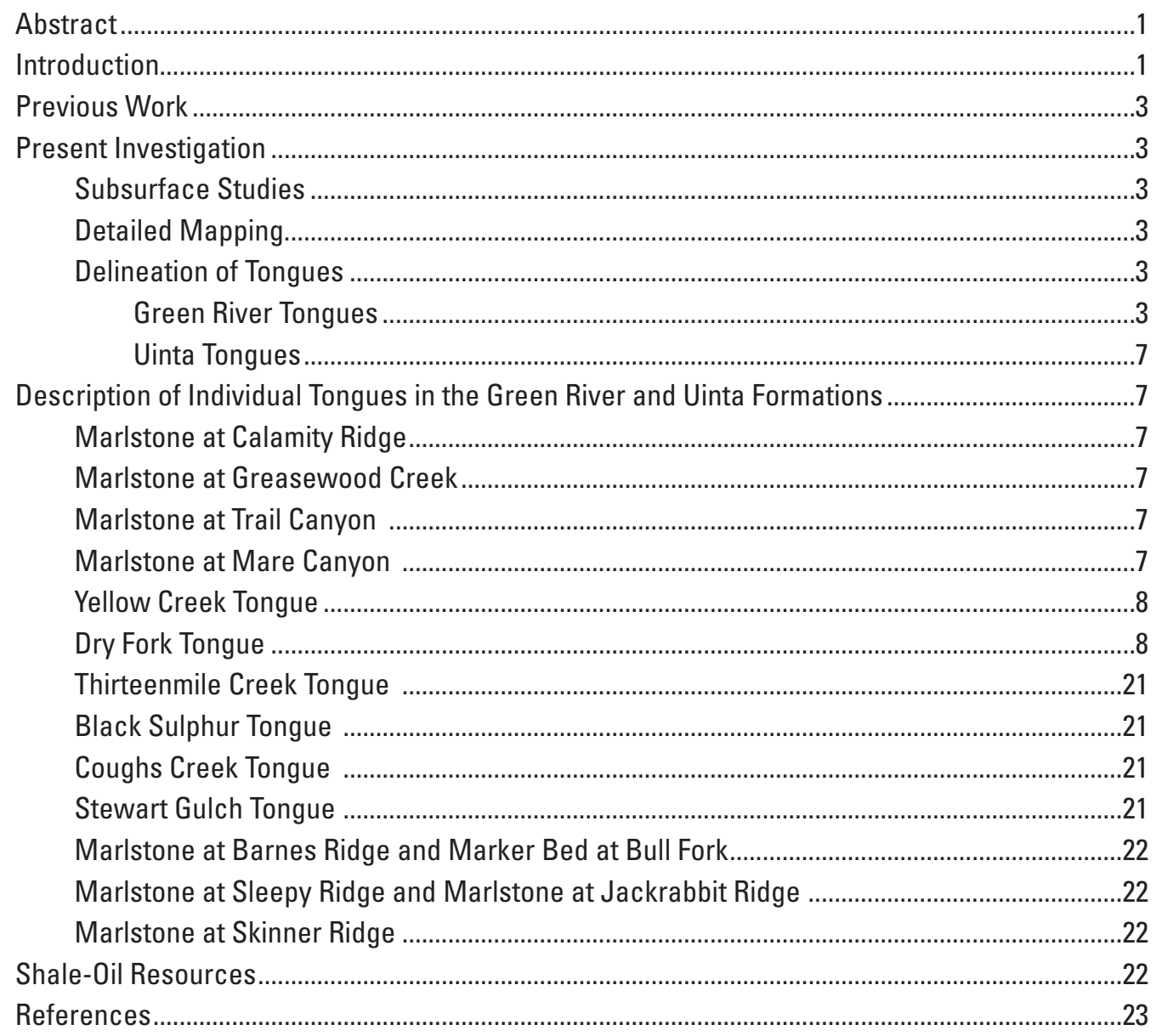




\section{Figures}

1. Map showing location of the Piceance Creek Basin study area between the Colorado and the White Rivers in northwestern Colorado. ...........................2

2. Map showing location of data used in North-South cross section. ....................................4

3. North-South cross section depicting the encroachment of fluvial sediments of the Uinta Formation into a 500 foot thickness of the Green River Formation from Sec. 13, T. 1 N., R. 98 W. to Sec. 24, T. 7 S., R. 97 W......... in back of report

4. Cross section showing the correlation of individual numbered oil shale beds and groups of beds in the upper part of the Green River Formation (modified from Donnell, 1997)...

5. Published Geologic quadrangle maps in the area of this report. (modified from an unpublished map by Hail). .6

6. Map showing location of data used in cross sections $A-A^{\prime}, C-C^{\prime}, E-E^{\prime}, G-G^{\prime}$, and $\mathrm{I}-\mathrm{I}^{\prime}$......

7. Cross section $A-A^{\prime}$ showing Green River Tongue Tggc .10

8. Map showing location of data used in cross sections $B-B^{\prime}, D-D^{\prime}, F-F^{\prime}$, $\mathrm{H}-\mathrm{H}^{\prime}$, and $\mathrm{J}-\mathrm{J}^{\prime}$ .11

9. Cross section B-B' showing Green River Tongue Tgtc. ................................................12

10. Cross section $\mathrm{C}-\mathrm{C}^{\prime}$ showing Green River Tongue Tgm ..................................................13

11. Cross section D-D' showing Green River Tongue Tgy....................................................14

12. Cross section E-E' showing Green River Tongue Tgt......................................................15

13. Cross section F-F' showing Green River Tongue Tgb ..................................................16

14. Cross section $\mathrm{G}-\mathrm{G}^{\prime}$ showing Green River Tongue Tgc................................................17

15. Cross section $\mathrm{H}-\mathrm{H}^{\prime}$ showing Green River Tongue Tgs....................................................18

16. Cross section I-I' showing Green River Tongue Tgj....................................................19

17. Cross section $\mathrm{J}-\mathrm{J}^{\prime}$ showing Green River Tongue Tgsk ................................................20

\section{Tables}

1. Mapped Green River Formation tongues in the Piceance Creek Basin, Northwestern Colorado. ...8

2. List of drill holes shown on cross sections . 


\title{
Intertonguing of the Lower Part of the Uinta Formation with the Upper Part of the Green River Formation in the Piceance Creek Basin during the Late Stages of Lake Uinta
}

\author{
By John R. Donnell
}

\section{Abstract}

During most of middle Eocene time, a 1,500- $\mathrm{mi}^{2}$ area between the Colorado and White Rivers in northwestern Colorado was occupied by the Piceance lobe of Lake Uinta. This initially freshwater lake became increasingly saline throughout its history. Sediments accumulating in the lake produced mostly clay shale, limestone, and dolomite containing varying concentrations of organic matter.

At the time of the maximum extent of the lake, the organic-rich Mahogany bed of the Green River Formation was deposited throughout the area. Shortly after its deposition, stream deposits began infilling the lake from the north through a series of contractions interspersed with minor expansions. This fluctuation of the shoreline resulted in the intertonguing of the stream sediments of the lower part of the overlying Uinta Formation with the lacustrine sediments of the upper part of the Green River over a distance of about $40 \mathrm{mi}$; construction of regional stratigraphic cross sections show the pattern of intertonguing in considerable detail.

The data utilized in this study, which covered parts of Rio Blanco, Garfield, and Mesa counties, was derived from (1) geologic mapping of thirty-four $7 \frac{1}{2} 2$-minute quadrangles and stratigraphic studies by geologists of the U.S. Geological Survey, and (2) shale-oil assay information from numerous cores. As a result of this previous work and the additional effort involved in the compilation here presented, more than a dozen Green River Formation tongues have been named, some formally, others informally.

Middle Eocene strata above the Mahogany bed in the northern part of the study area are dominantly coarse clastics of the Uinta Formation. The sedimentary sequence becomes more calcareous and organic-rich to the south where, in a 400- $\mathrm{mi}^{2}$ area, a $250 \mathrm{ft}$-thick sequence of oil shale above the Mahogany bed contains an average of 16 gallons of oil per ton of shale and is estimated to contain 73 billion barrels of oil.

\section{Introduction}

The Piceance Creek Basin is a large structural and depositional basin of several thousand square miles in northwestern Colorado, extending from the Axial uplift in the north to the Gunnison uplift in the south and from the White River uplift on the east to the Douglas Creek Arch to the west. During a period of several million years in the middle Eocene, most of the basin was occupied by the Piceance Lobe of Lake Uinta, a large body of water that covered much of northwestern Colorado and northeastern Utah (Franczyk and others, 1992). Throughout its history, coarse clastics were shed into the marginal areas of the lake while organic-rich material that formed the oil shale beds of the Green River Formation was deposited in the open lacustrine area. A sequence of rich oil shale beds named the "Mahogany Ledge" were deposited during the time of maximum extent of the lake. The Mahogany bed in the upper third of that sequence is about $10 \mathrm{ft}$ thick and in much of the area yields an average of 50 gallons of oil per ton of shale. The unit is resistant to erosion and forms a prominent ledge in exposures along the south margin of the basin. The coarse clastic beds that underlie and intertongue with the oil shales below the Mahogany bed are in the Wasatch Formation and those that overlie and intertongue with the oil shales above the Mahogany bed are in the Uinta Formation.

Concern about a possible shortage of petroleum products in the United States in the 1940s created considerable interest in possible utilization of oil from oil shale to help meet the nation's energy needs. The federal government and major oil companies initiated a core-hole drilling program and the U.S. Geological Survey initiated a detailed geological mapping program in a $1,500-\mathrm{mi}^{2}$ area of the Piceance Creek Basin (fig. 1) between the Colorado River on the south and the White River on the north. Assays of the oil shale from several hundred cores combined with the mapping data provided the information needed to prepare a comprehensive shale-oil resource 


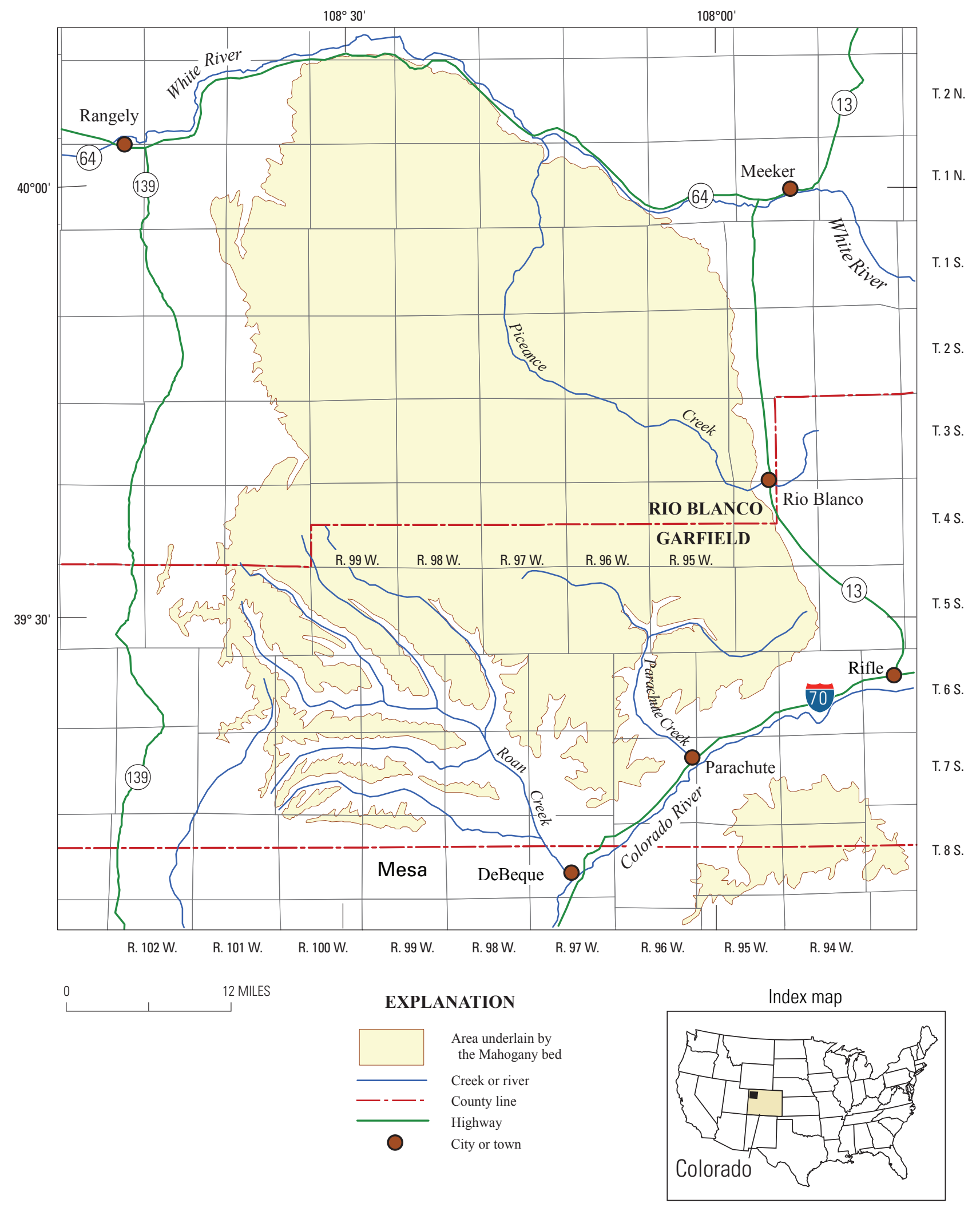

Figure 1. Location of the Piceance Creek Basin study area between the Colorado and the White Rivers in northwestern Colorado. 
appraisal of the Piceance Creek Basin (Pitman and Johnson, 1978; Pitman and others, 1989).

\section{Previous Work}

The extensive core-hole drilling and detailed mapping delineated the complex intertonguing of the upper part of the Green River Formation with the lower part of the Uinta Formation in the Piceance Creek Basin. Most of the prominent Green River tongues were formally named, whereas the Uinta tongues received no formal designation but were labeled either by letter or number varying from quadrangle to quadrangle.

The type localities of most tongues are a considerable distance from the area where they join the main body of the Green River Formation. Therefore, the identification of individual organic-rich oil shale beds in a given tongue at its type locality is difficult because of the dilution of organic fraction by clastic sediments.

Surface and subsurface data indicate that relatively soon after the deposition of the Mahogany bed, the Piceance Lobe of Lake Uinta began to infill from the north with clastic material of the Uinta Formation. The lowermost Uinta tongue is less than $10 \mathrm{ft}$ above the Mahogany bed in a small area located in Ts. 1 and 2 N., and Rs. 99 and 100 W. in the northwest corner of the basin (fig. 1). As infilling progressed from the north, lacustrine deposition continued in the southern part of the basin. Throughout much of the period of infilling by clastic sediments in the north, a continuous sequence of oil shale more than $400 \mathrm{ft}$ thick was deposited above the Mahogany bed in a northwest-trending area from T. 7 S., R. 94 W. to T. 6 S., R. 99 W. in the southern part of the basin (fig. 1). A number of cross sections have been published showing the intertonguing throughout the basin, utilizing both surface and subsurface data; however, none makes a precise tie between specific Uinta tongues and individual persistent organic rich oil shale beds (O’Sullivan, 1974; 1987; Hail, 1987; 1990; 1992).

\section{Present Investigation}

The present study utilized the data from detailed mapping and stratigraphic studies, as well as shale-oil assay data from numerous cores in the Piceance Creek Basin to show a direct tie between identifiable of rich oil shale beds in the upper part of the Parachute Creek Member of the Green River Formation with individual clastic beds or groups of beds in the lower part of the Uinta Formation (figs. 2 and 3). The assumption is that zones in cores that have little or no shale-oil content are siltstones or sandstones of the Uinta Formation (as shown by assay values in fig. 3); several such zones in core holes C 34 and $\mathrm{C} 35$ can be correlated with oil shale tongues in adjacent core holes, as indicated. Identification of individual or groups of oil shale beds contained in a Green River tongue is based on their comparison with numbered beds shown in figure 4 . Although several hundred sets of assays are available, there are some areas with no data. Positive identification of individual oil shale beds is difficult where assay intervals are greater than two feet. Uinta tongues consist of clastic beds that underlie and intertongue with the laterally equivalent tongues of the Green River Formation; tongues of the Uinta Formation are numbered from oldest to youngest (fig. 4).

\section{Subsurface Studies}

Assay data from selected cores in boreholes throughout the Piceance Creek Basin were examined to determine the relation of each Uinta tongue to the numbered oil shale beds shown in figure 4. Cross sections of individual tongues were prepared using assay sets from holes drilled close to where a given Green River tongue joins the main body of the formation; these sets were then correlated with other sets at some distance from the join. Positive identification of individual oil shale beds is difficult in core holes with large assay intervals, therefore only wells with one- or two-foot assay intervals were used. Individual Uinta tongues in the cross sections include sandstone and siltstone beds that underlie and intertongue with the Green River.

\section{Detailed Mapping}

Geologic mapping was initiated in 1960 in the first of 34 U.S. Geological Survey 1:24,000-scale 71/2-minute quadrangle maps in the Piceance Creek Basin (fig. 5), and continued until the late 1980s. Initially, individual tongues of the Green River Formation were not differentiated in outcrops where they were interbedded with units consisting of Uinta Formation lithologies, therefore the tongues were not mapped on many of the earliest published geologic quadrangles. During the present investigation, in areas where tongues are mapped to the margin of one quadrangle, however, they are extended into adjacent quadrangles where they were not initially mapped. In some areas close to the merger of a Green River tongue with the main body of the formation, the associated Uinta tongue is too obscured to be mapped; however, the tongue's presence can be determined, based on assays of core samples.

\section{Delineation of Tongues}

\section{Green River Tongues}

The Green River tongues are characterized in much of the Piceance Creek Basin by prominent light-gray to white bands separated by thick, brown, slope-forming sandstones of the Uinta Formation along Piceance Creek and Yellow Creek and their major tributaries. The lithology at most type localities consists dominantly of light-gray to white marlstone, with 


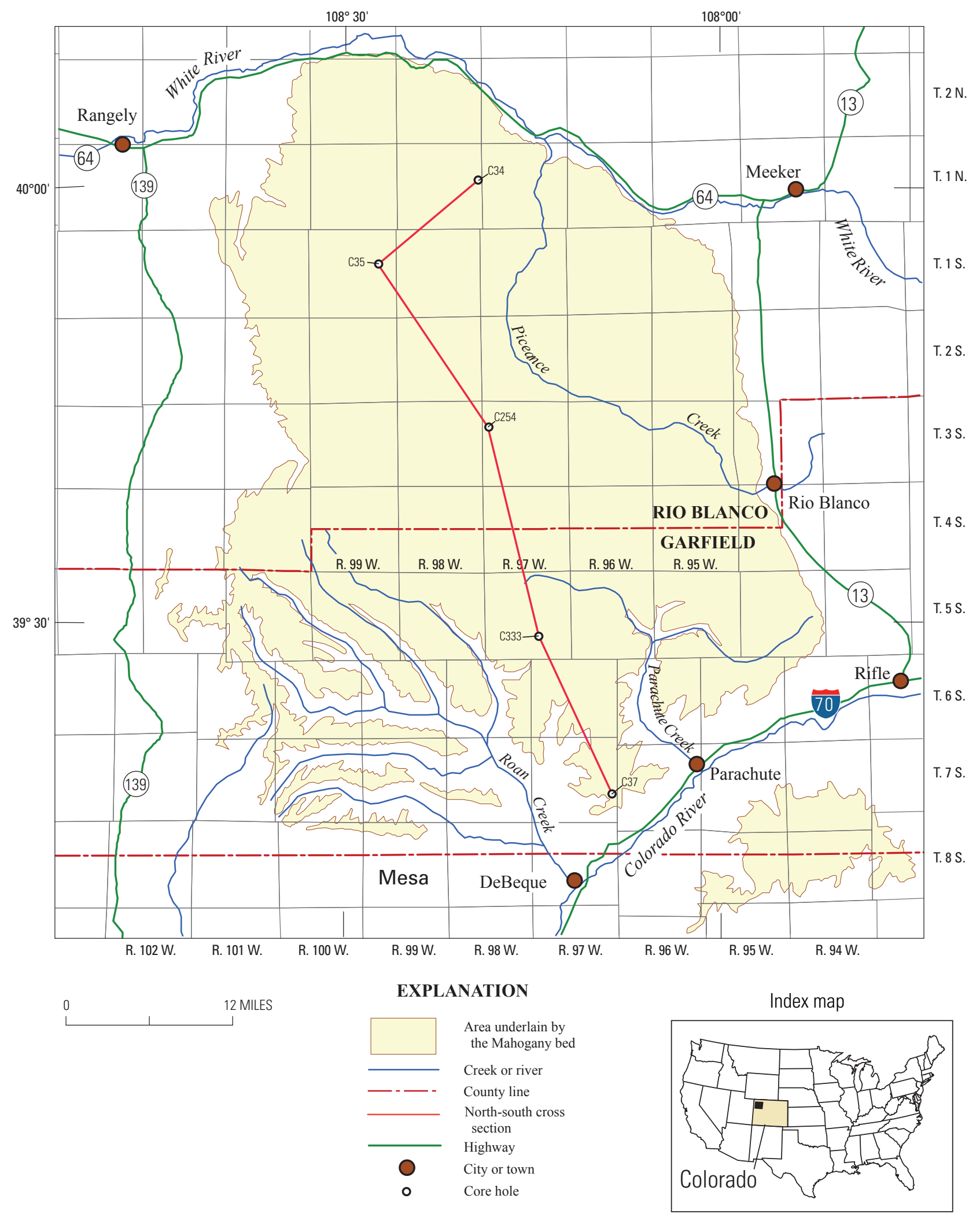

Figure 2. Location of cross section in figure 3. 
C37

U.S. Bureau of Land Management

Triangulation Station Shale 2

Sec. 24, T. 7 S., R. 97 W.

Garfield County, Colo.

U31

Skyline Oil Company

Watson 1

Sec. 5, T. 11 S., R. 25 E.

Uintah County, Utah

Oil yield in gallons per ton

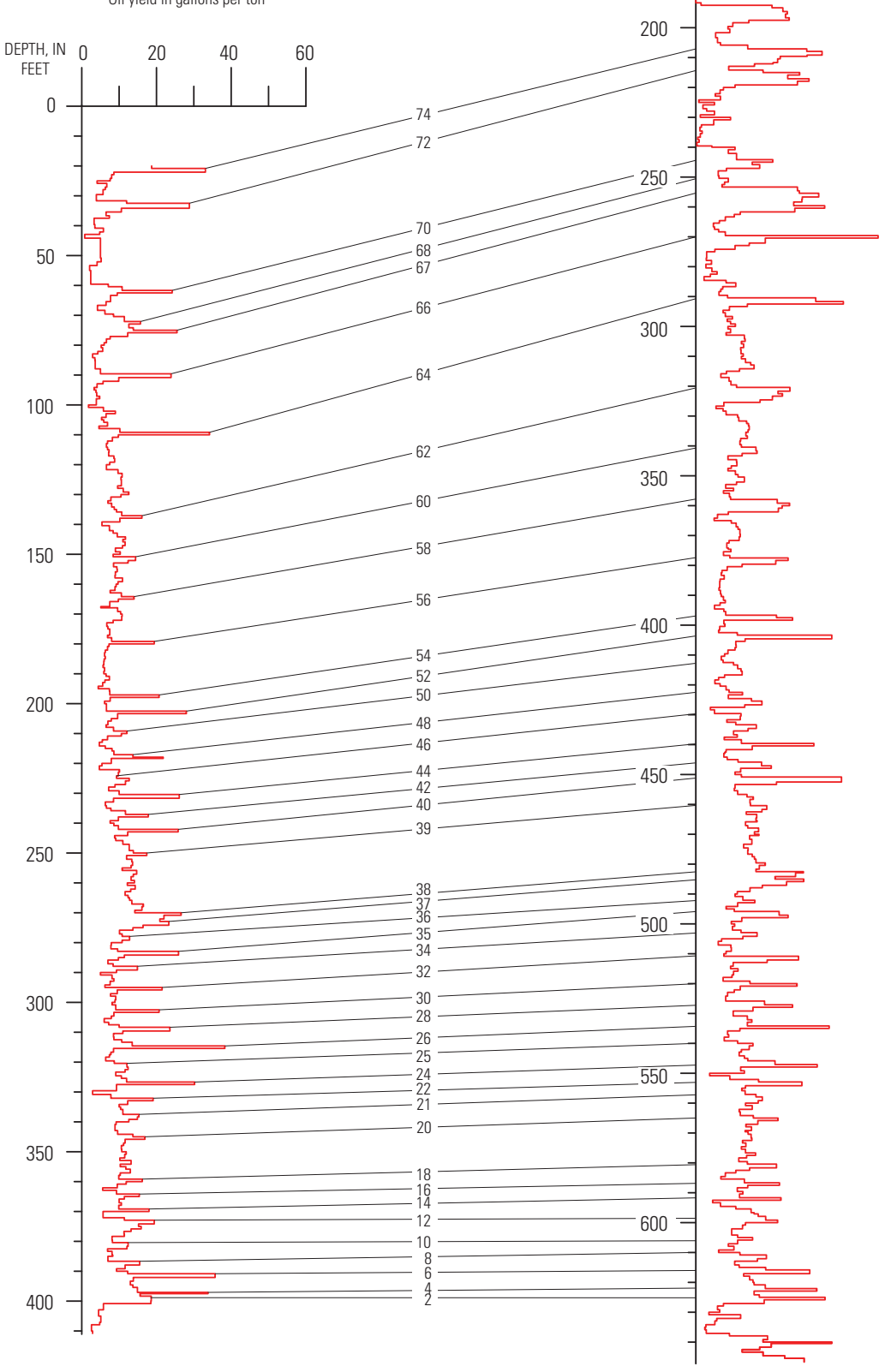

Oil yield in gallons per ton
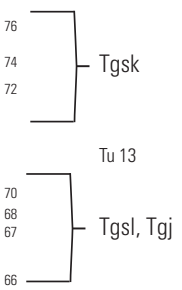

Tu12

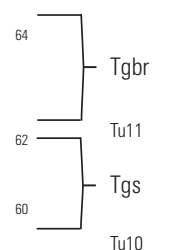

${ }_{56} \longrightarrow$ Tgc

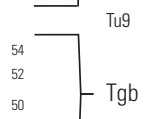

${ }_{46}^{48} \rightleftharpoons \quad$ Tu8

$\begin{aligned} & 44 \\ & 42 \\ & 40\end{aligned} \quad-$ Tgt

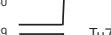

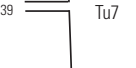

$38 \quad-T$

${ }_{35}^{36}$

$34=$ Tu6

- Tgy Tu5

$22 \quad-$ Tgm

${ }_{20}^{21}=$ Tu4

$18 \quad$ Tgtc

${ }^{14} \rightleftharpoons$ Tu3

$\left.\begin{array}{l}12 \\ 10 \\ 8 \\ 6 \\ 4 \\ 2\end{array}\right]-$ TggC

"A" Tu2

Figure 4. Cross section showing correlation of individual oil shale beds (numbered 2-76) and groups of beds forming named tongues (indicated by stratigraphic unit symbols) in the upper part of the Green River Formation. Stratigraphic units labeled "Tu" are tongues of Uinta Formation. Symbols for beds and tongues are defined in table 1. From Donnell, 1997. 


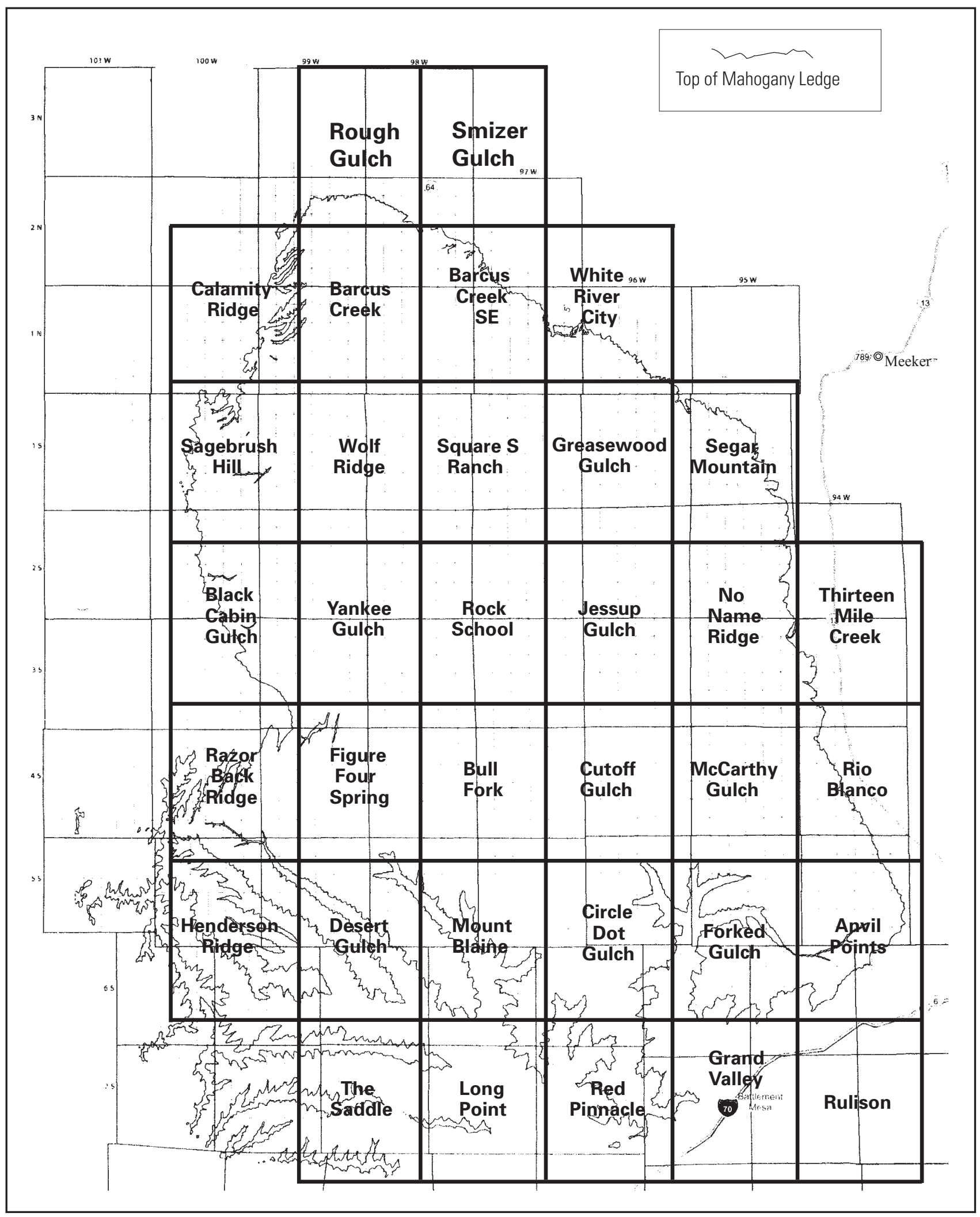

Figure 5. Locations of published U.S. Geological Survey 1:24,000-scale 71/2-minute quadrangle maps in the Piceance Creek Basin, northwestern Colorado. 
little or no organic content, and minor amounts of siltstone and sandstone, algal and oolitic limestone, and, locally, thin beds of oil shale. Traced to the south from the type localities, the tongues generally contain a higher percentage of organic material and join the main body of the Green River Formation where they contain identifiable rich oil shale beds. Traced to the north from the type localities, the tongues generally have a higher percent of sandstone and siltstone as they merge into the Uinta Formation.

\section{Uinta Tongues}

At the type locality of each Green River tongue, the immediately underlying Uinta tongue is assigned a number (see figs. 3 and 4) and described in the text. South of the type locality of the Green River tongue, the sandstone of the underlying Uinta tongue thins and wedges out, whereas north of the type locality of the Green River tongue, the underlying Uinta sandstone tongue thickens and merges with the next higher Uinta tongue.

\section{Description of Individual Tongues in the Green River and Uinta Formations}

Table 1 lists the particular publication wherein a given tongue is named and described in detail. This report describes the relation of each Green River and Uinta tongue according to the numbered beds and named units shown in figures 3 and 4. The geographic extent of each tongue is estimated based on detailed surface mapping within the quadrangle areas shown in figure 5 and on subsurface data derived from assays of core plotted on a series of cross sections $\left(\mathrm{A}-\mathrm{A}^{\prime}\right.$ to $\left.\mathrm{J}-\mathrm{J}^{\prime}\right)$ presented in figures 7 and 9 through 17 . Locations of cross sections are shown in figures 6 and 8 .

\section{Marlstone at Calamity Ridge}

The lowermost oil shale tongue of the Green River Formation, here named informally as the "Marlstone at Calamity Ridge" (Tgcr, fig. 3) lies above the Mahogany bed. It is entirely within the upper part of a unit termed the "Mahogany Ledge". The tongue extends from the "Mahogany Marker" at its base, which is a thin analcimized tuff bed above the Mahogany bed, upward to the base of "A Groove" that is the upper contact of the Mahogany Ledge. The lowest tongue of the Uinta Formation (distinguished as Tu1; it is not shown in figures or tables) consists of a basal sandstone at the "Mahogany marker" and two other sandstone beds higher in the section. The Tgcr and Tu1 unit appear to be restricted to a small area in the north half of the Calamity Ridge, Barcus Creek, and Barcus Creek SE quadrangles (fig. 5) and have been mapped as part of the Parachute Creek Member of the Green River Formation.

\section{Marlstone at Greasewood Creek}

The "Marlstone at Greasewood Creek," near the area where it joins the main body of the Green River Formation, contains oil shale beds 2 through 12 that form tongue Tggc (fig. 4; see cross section A-A'; figs. 6 and 7). A persistent sandstone in "A Groove" is the basal unit in underlying Uinta tongue Tu2. The sandstone that directly overlies the tongue Tggc is probably the lateral equivalent of the wavy-bedded tuff in the southern part of the Piceance Creek Basin. Tongue Tggc may be traced in the subsurface into the White River City quadrangle, the northeastern part of the Square S Ranch quadrangle, most of the Sagebrush Hill quadrangle and the southern third of the Wolf Ridge quadrangle (fig. 5). It merges with the Uinta Formation in the southwest quarter of the Barcus Creek SE quadrangle, and the northwest quarter of the Wolf Ridge quadrangle and joins the main body of the Green River Formation on the southern edge of the Sagebrush Hill and Wolf Ridge quadrangles and central part of the Square $S$ Ranch quadrangle (fig. 5). Figs. 6-9 near here

\section{Marlstone at Trail Canyon}

The Green River tongue distinguished as the "Marlstone at Trail Canyon" (Tgtc, fig. 4; cross section B-B'; figs. 8 and 9) was informally named by Hail (1984) for exposures along Trail Canyon in the Calamity Ridge quadrangle. At the type locality it is mostly light-gray marlstone with lesser amounts of siltstone. The tongue has been mapped in the Barcus Creek, Barcus Creek SE and the Calamity Ridge quadrangles and traced in the subsurface into the northern part of the Wolf Ridge quadrangle (fig. 5). It joins the main body of the Green River Formation in the southern part of the Calamity Ridge quadrangle and grades into Uinta Formation tongue Tu3 in the northwest quarter of the Barcus Creek quadrangle. Tongue Tgtc contains oil shale beds 16, 18, and 20 (fig. 4). The basal sandstone in Tu3 is the lateral equivalent to a unit called the "wavy bed," a prominent tuff bed in the southern part of the basin. Tu3 has been labeled Tub, Tu2 and Tucb on various published quadrangles.

\section{Marlstone at Mare Canyon}

The tongue "Marlstone at Mare Canyon" (Tgm, fig. 4; cross section $\mathrm{C}-\mathrm{C}$ ', figs. 6 and 10) was informally named by Hail (1984) for exposures in the NW1/4 sec. 34, T. $1 \mathrm{~N}$., R. 99 W., along Trail Canyon just east of the mouth of Mare Canyon. At the type locality, it consists mostly of light-gray silty marlstone and marly siltstone. In the vicinity of its join with the main body of the Green River Formation, tongue Tgm contains rich oil shale beds 22, 24 and 25. In places, a sandstone bed as much as $40 \mathrm{ft}$ thick separates beds 24 and 25 (fig. 10). The unit has been mapped in the Barcus Creek, Barcus Creek SE, and Calamity Ridge quadrangles (fig. 5); in the Sagebrush Hill quadrangle it has been mapped by Donnell 
Table 1. Mapped Green River Formation tongues in the Piceance Creek Basin, northwestern Colorado.

[USGS, U.S. Geological Survey; MF, Miscellaneous Field Studies Maps; Bull., Bulletin; GQ, Geologic Quadrangle Maps]

\begin{tabular}{lcccl}
\hline \multicolumn{1}{c}{ Name } & $\begin{array}{c}\text { Map } \\
\text { Symbol }\end{array}$ & $\begin{array}{c}\text { Status of } \\
\text { Name }\end{array}$ & $\begin{array}{c}\text { Underlying } \\
\text { Uinta Tongue }\end{array}$ & Publication \\
\hline Marlstone at Skinner Ridge & Tgsk & Informal & Tu13 & USGS Map MF-984 (Hail, 1978) \\
Marlstone at Sleepy Ridge & Tgsl & Informal & Tu12 & USGS Map MF-984 (Hail, 1978) \\
Marlstone at Jackrabbit Ridge & Tgj & Informal & Tu11 & USGS Map MF-1293 (Hail, 1984) \\
Stewart Gulch Tongue & Tgs & Formal & Tu10 & USGS Bull. 1422-E \\
Coughs Creek Tongue & Tgc & Formal & Tu9 & USGS Bull. 1395 (O'Sullivan, 1975) \\
Black Sulphur Tongue & Tgb & Formal & Tu8 & USGS Bull. 1394-F (Duncan and others, 1974) \\
Thirteen Mile Creek Tongue & Tgt & Formal & Tu7 & USGS Bull. 1394-F (Duncan and others, 1974) \\
Dry Fork Tongue & Tgd & Formal & Tu6 & USGS Bull. 1394-F (Duncan and others, 1974) \\
Yellow Creek Tongue & Tgy & Formal & Tu5 & USGS Bull. 1394-F (Duncan and others, 1974) \\
Marlstone at Mare Canyon & Tgm & Informal & Tu4 & USGS GQ 1578 (Hail, 1984) \\
Marlstone at Trail Canyon & Tgtc & Informal & Tu3 & USGS GQ 1578 (Hail, 1984) \\
Marlstone at Greasewood Creek & Tggc & Informal & Tu2 & This report \\
Marlstone at Calamity Ridge & Tgcr & Informal & Tu1 & This report \\
\hline
\end{tabular}

(1982) as Tgdc. In the subsurface, the tongue has been identified in the Wolf Ridge quadrangle in core hole C35 (fig. 10). The "Marlstone at Mare Canyon" in the northeastern part of the Barcus Creek SE quadrangle has been mapped as tongues $\mathrm{Tg} 3$ and $\mathrm{Tg} 4$, the lateral equivalent of Uinta tongues $\mathrm{Tu} 3$ and Tu4 which are combined in this report as Tu4 (fig. 10). The unit has not been mapped separately in the White River City quadrangle nor identified in the subsurface, probably because it has graded into the Uinta Formation.

\section{Yellow Creek Tongue}

The Yellow Creek tongue (Tgy, fig. 4; cross section D-D', figs. 8 and 11) was named by Duncan and others (1974) from exposures on the east side of Yellow Creek in the NE1/4 SE $1 / 4$ sec. 13, T. 1 N., R. 98 W. about $150 \mathrm{ft}$ southeast of U.S. Bureau of Mines AEC core hole 1. At the type locality it is 45 ft thick and comprised mainly of light-gray to medium-brown silty marlstone with minor thin interbeds of light-gray to lightbrownish gray beds of siltstone and a one-foot-thick mediumgrained sandstone bed. Near where the tongue merges with the main body of the Green River Formation, it consists almost entirely of oil shale, including the four organic-rich beds (nos. $26,28,30$, and 32; figs. 4 and 11) that have been termed "the 4 senators" in the area just north of the Colorado River (fig. 1). Tongue Tgy has been mapped in the White River City, Barcus Creek, Barcus Creek SE, and Greasewood Gulch quadrangles (fig. 5); it has also been recognized in the southern part of the
Rough Gulch quadrangle, as well as in the subsurface of the Wolf Ridge, Square S Ranch, and Black Cabin Gulch quadrangles. The magnitude of the intertonguing between the Green River and Uinta Formations in the basin is demonstrated by the thickening of the interval between the base of the Yellow Creek tongue and the top of "A Groove", from $90 \mathrm{ft}$ in the triangulation-station-shale core hole in sec. 24, T. 7 S., R. 97 W. (fig. 4) to 1,000 ft in the U.S. Bureau of Mines/AEC Core hole No. 1 sec. 13, T. 1 N., R. 98 W. (Hail, 1987).

\section{Dry Fork Tongue}

The Dry Fork tongue was named by Duncan and others (1974) from exposures in $\mathrm{NE}^{1 / 4} \mathrm{SE}^{1 / 4} \mathrm{NW}^{1 / 4} \mathrm{sec}$. 35, T. $1 \mathrm{~N}$., R. 97 W., along the Dry Fork of Piceance Creek. At the type locality it is $70 \mathrm{ft}$ thick and consists of greenish gray marlstone, silty marlstone, and calcareous siltstone with a 5- to 10-ft light-brown sandstone lens near the base. In the area where the tongue merges with the main body of the Green River Formation, it consists entirely of oil shale, including organic-rich beds 36 through 38 . Where well developed, the sequence (labeled Tgd, fig. 4) has been called the Stillwater zone. Tongue Tgd has been mapped in parts of the White River City, Barcus Creek, Barcus Creek SE, Greasewood Gulch, and Segar Mountain quadrangles (fig. 5). The Dry Fork tongue is underlain by, and grades laterally into, Uinta tongue Tu6 (fig. 4); a cross section was not prepared for this report because of the lack of adequate data. 


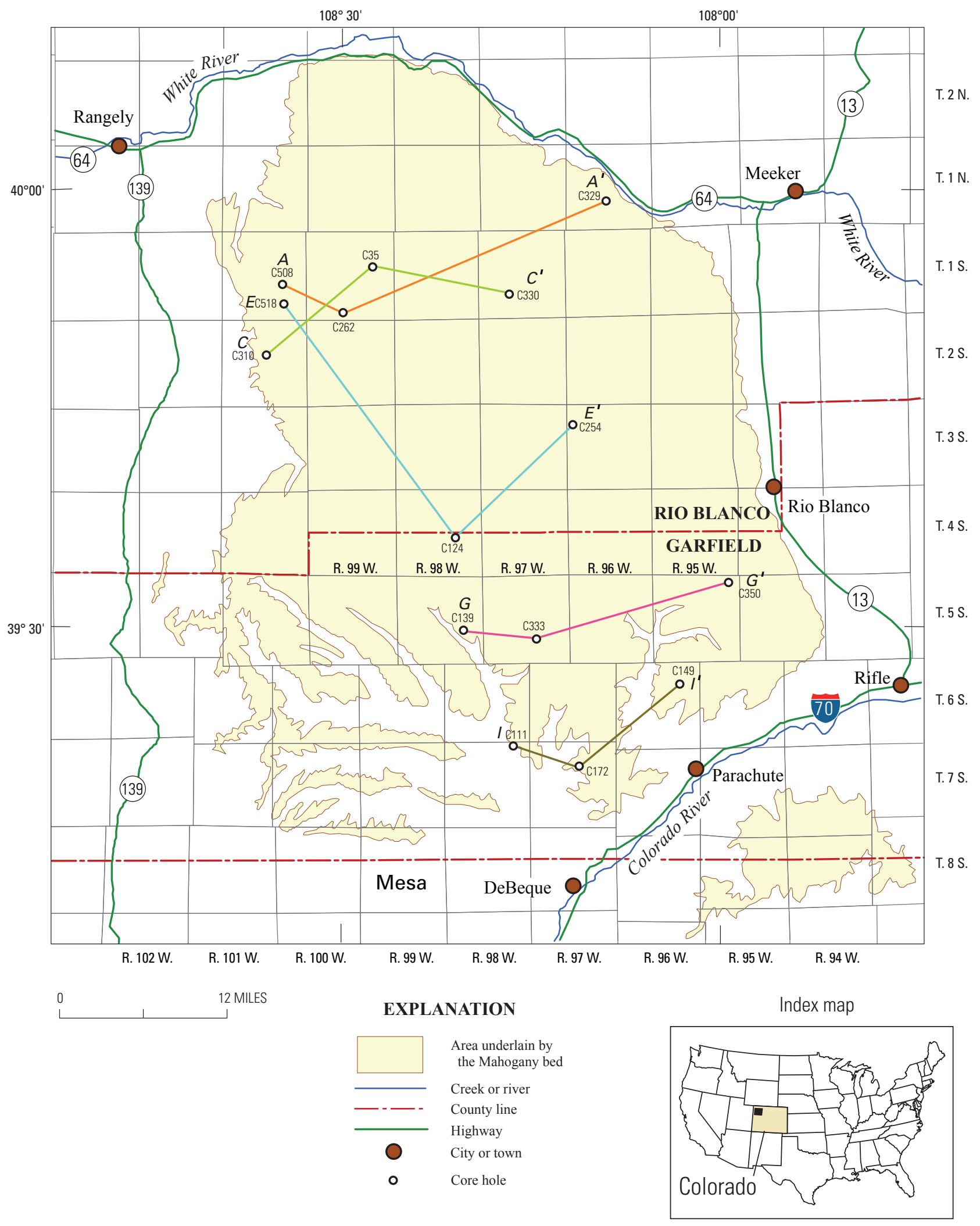

Figure 6. Locations of cross sections $A-A^{\prime}$ (fig. 7), $C-C^{\prime}$ (fig. 10), $E-E^{\prime}$ (fig. 12), $G-G^{\prime}$ (fig. 14), and $I-Y^{\prime}$ (fig. 16). 
Phillips Petroleum Co., P-02 Sec. 23, T. 1 S., R. 100 W.

Gulf/Std. Ind. (Ca Project) Ch 2-3 Sec. 33, T. 1 S., R. 99 W.
A'

C329

Carter Oil Co., Opportunity 2 Sec. 28, T. 1 N., R. 96 W.

$$
\begin{gathered}
\text { DEPTH, IN } \\
\text { FEET }
\end{gathered}
$$

300

DEPTH,
FEET

400

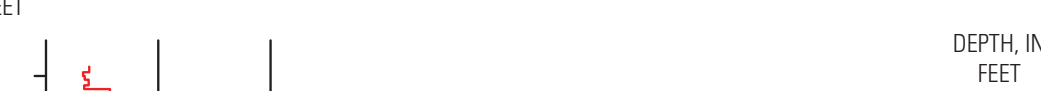

450

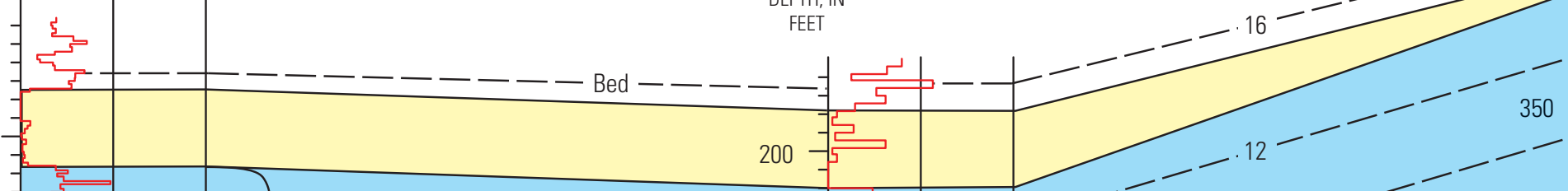

500

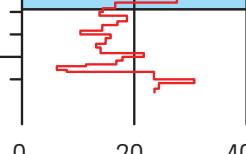

Oil yield in gallons per ton

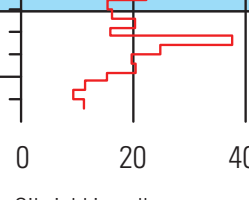

Oil yield in gallons per ton
-. 8

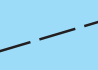

----1 Bed $---\frac{-}{250}$

A Groove

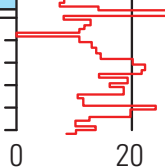

Oil yield in gallons per ton $\overrightarrow{0}$

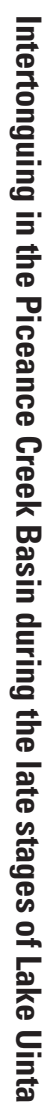

Figure 7. Cross section $A-A^{\prime}$ showing stratigraphic relation of tongue Tggc (table 1) of the Green River Formation (blue) with associated tongues of the Uinta Formation (yellow). The underlying Uinta tongue is labeled Tu2. Individual oil shale beds labeled 2-16. Location of section shown in figure 6. 


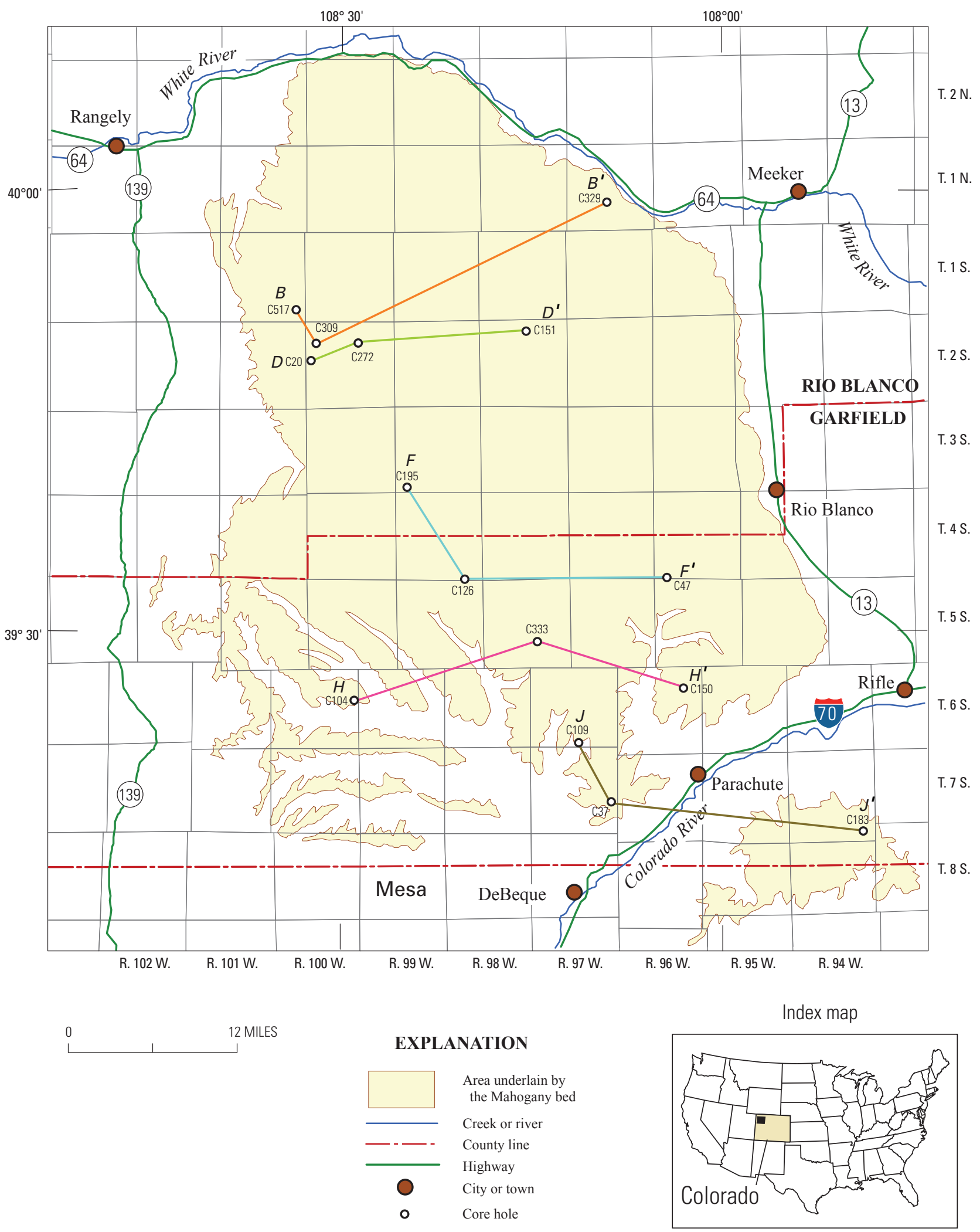

Figure 8. Locations of cross sections $B-B^{\prime}$ (fig. 9), $D-D^{\prime}$ (fig. 11), $F-F$ (fig. 13), $H-H^{\prime}$ (fig. 15), and $J-J^{\prime}$ (fig. 17). 
DEPTH, IN
FEET

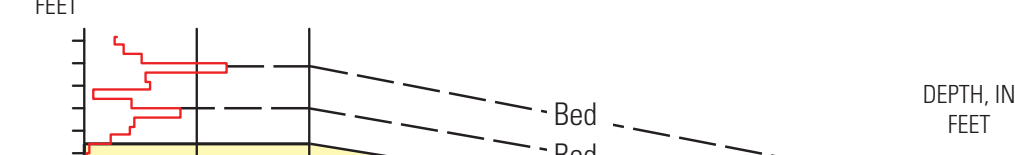

450

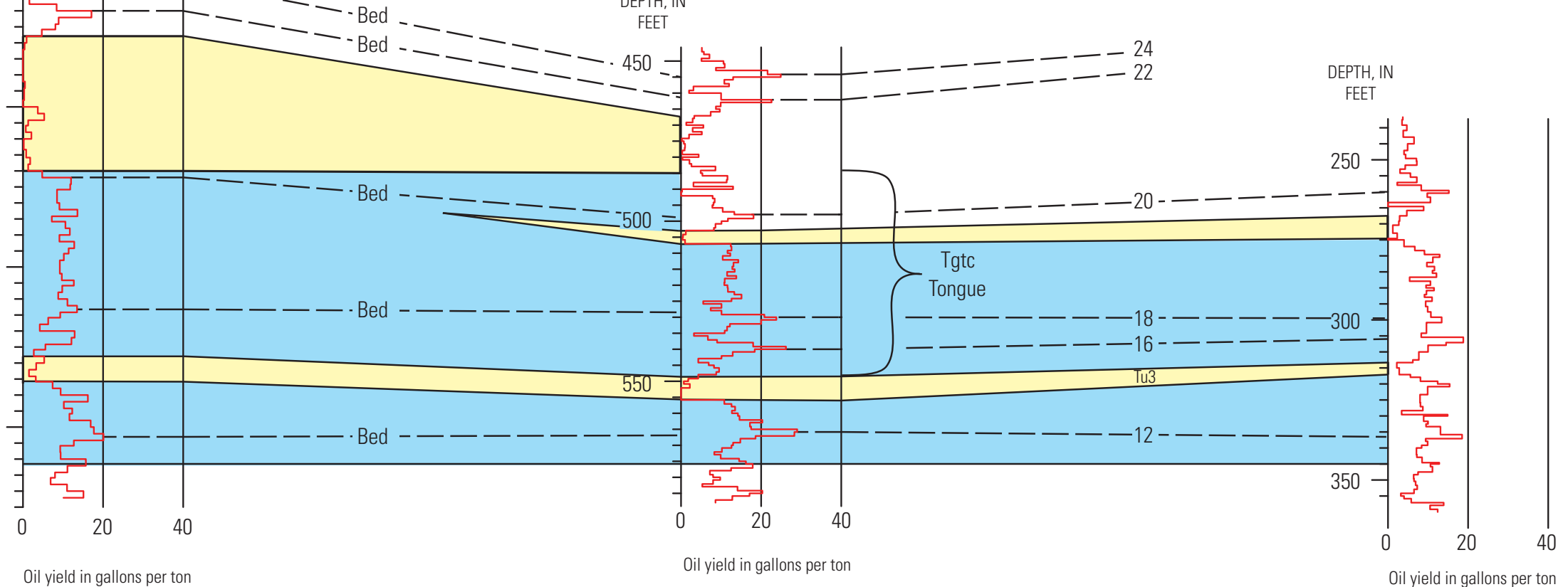

Figure 9. Cross section $B-B^{\prime}$ showing stratigraphic relation of tongue Tgtc (table 1) of the Green River Formation (blue) with associated tongues of the Uinta Formation (yellow). The underlying Uinta tongue is labeled Tu3. Individual oil shale beds labeled 12-24. Location of section shown in figure 8. 


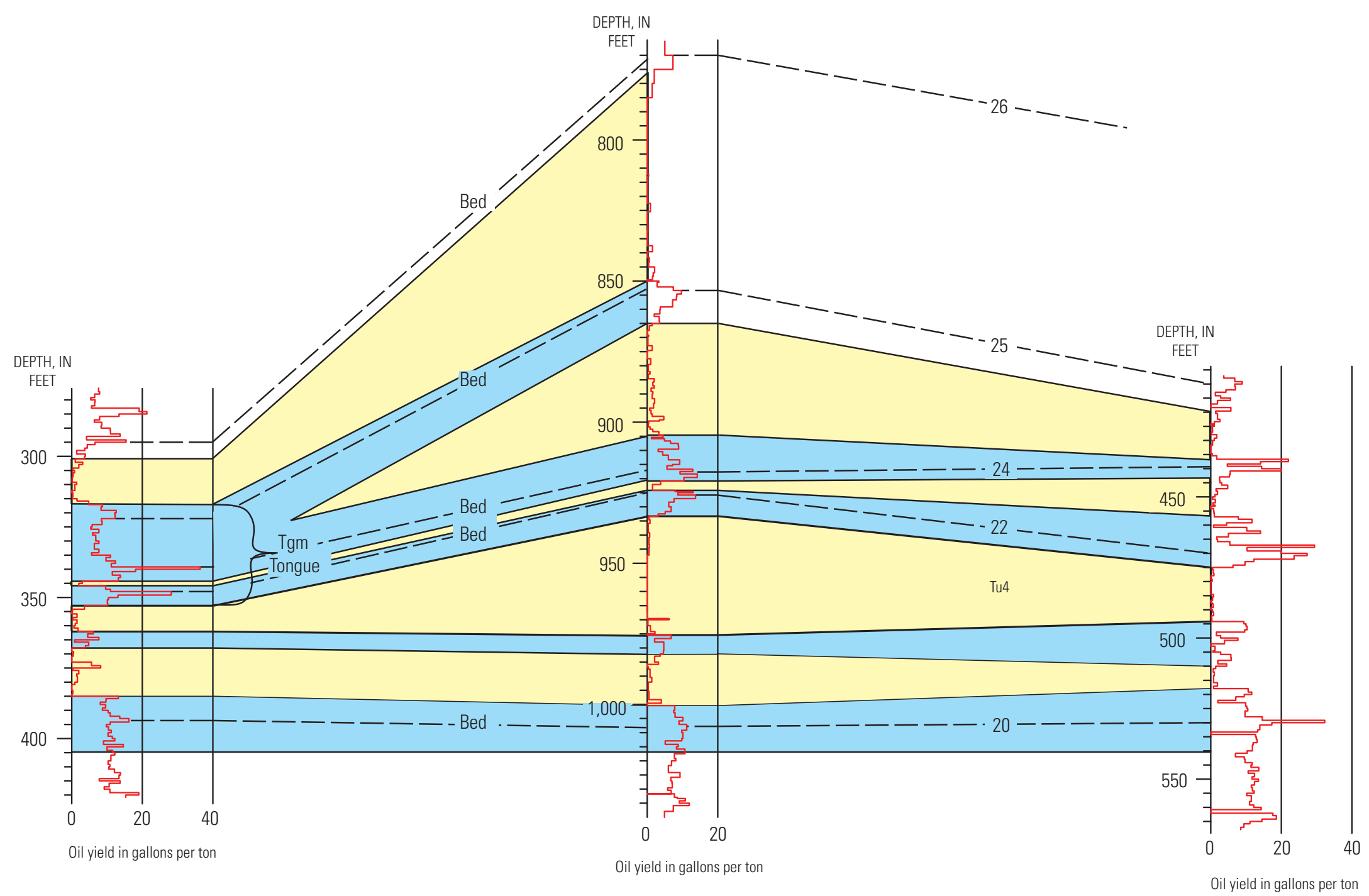

Figure 10. Cross section $C-C^{\prime}$ showing stratigraphic relation of tongue Tgm (table 1) of the Green River Formation (blue) with associated tongues of the Uinta Formation (yellow). The underlying Uinta tongue is labeled Tu4. Individual oil shale beds labeled 20-26. Location of section shown in figure 6. 
D

$\mathrm{C20}$

Tell Ertl Jan

Sec. 18, T. 2 S., R. 99 W.
C272

Rio Blanco Oil Shale Co., C-14

Sec. 10, T. 2 S., R. 99 W.
D'

C151

Marathon Oil Co., Square S No. Sec. 4, T. 2 S., R. 97 W.

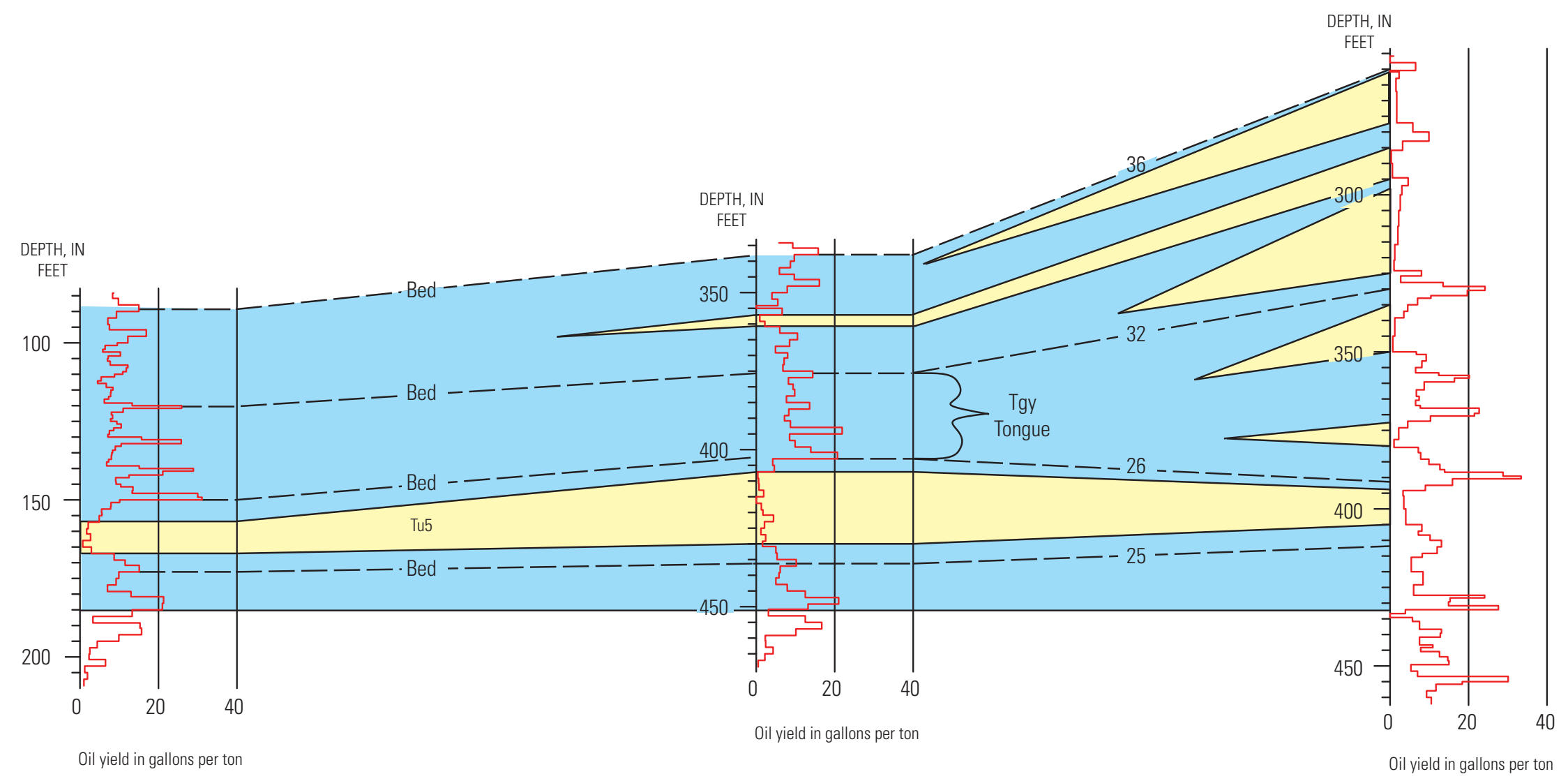

Figure 11. Cross section $D-D^{\prime}$ showing stratigraphic relation of tongue Tgy (table 1) of the Green River Formation (blue) with associated tongues of the Uinta Formation (yellow). The underlying Uinta tongue is labeled Tu5. Individual oil shale beds labeled 25-36. Location of section shown in figure 8. 


\section{DEPTH, IN}

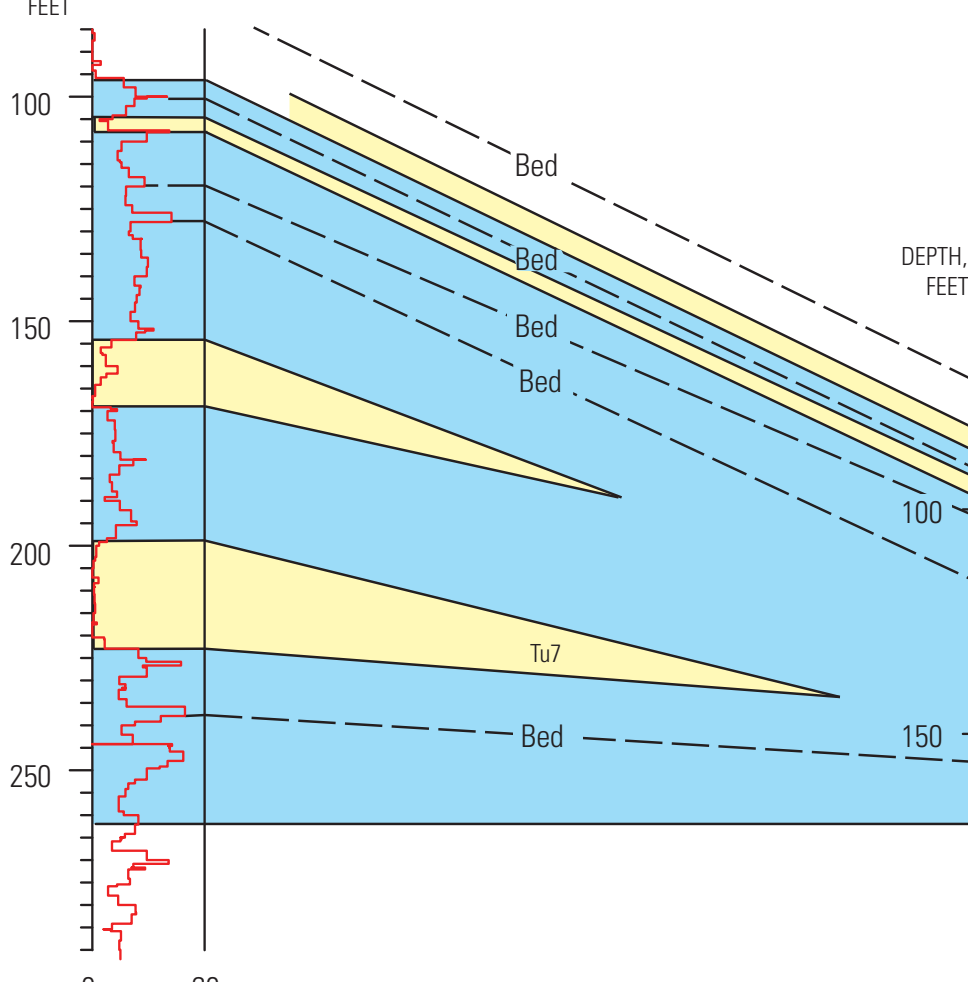

20

Oil yield in gallons per ton

Figure 12. Cross section $E-E^{\prime}$ showing stratigraphic relation of tongue Tgt (table 1) of the Green River Formation (blue) with associated tongues of the Uinta Formation (yellow). The underlying Uinta tongue is labeled Tu7. Individual oil shale beds labeled 38-48. Location of section shown in figure 6. 
ARCO-Mobil-Equity, Figure Four 31-1 Sec. 31, T. 3 S., R. 98 W.
C126 Sec. 35, T. 4 S., R. 98 W.

DEPTH, IN

FEET

150

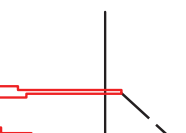

Savage Oil Shale Development Corp., Camp

C47

Union Oil Company, Florence Sec. 31, T. 4 S., R. 95 W.

DEPTH, IN

550

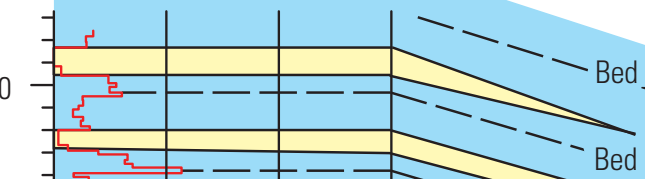

600

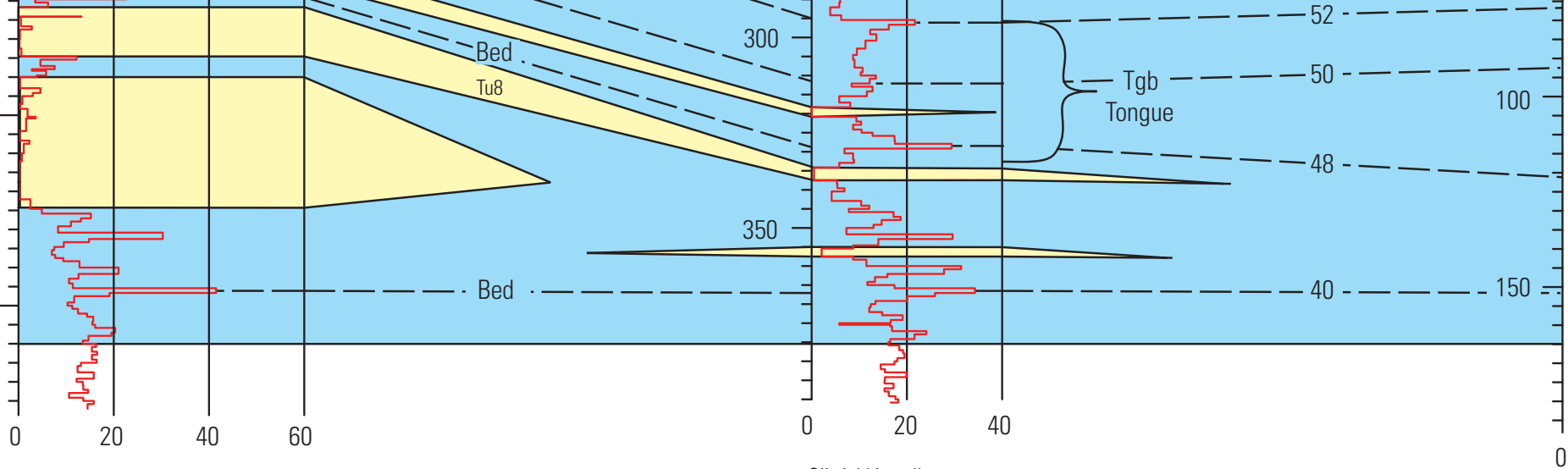

Oil yield in gallons per ton
Oil yield in gallons per ton $\vec{\sigma}$

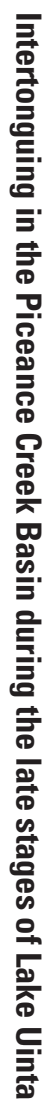

Figure 13. Cross section $F-F$ showing stratigraphic relation of tongue Tgb (table 1) of the Green River Formation (blue) with associated tongues of the Uinta Formation (yellow). The underlying Uinta tongue is labeled Tu8. Individual oil shale beds labeled 40-54. Location of section shown in figure 8. 


\section{。}

C139

Getty Oil Co., 01-23/D

Sec. 23, T. 5 S., R. 98 W.
C333

Getty Oil Co., 32-27 Sec. 27, T. 5 S., R. 97 W.
$G^{\prime}$

C350

U.S. Navy, Core Hole 15/16 (NOSR1) Sec. 1, T. 5 S., R. 95 W.

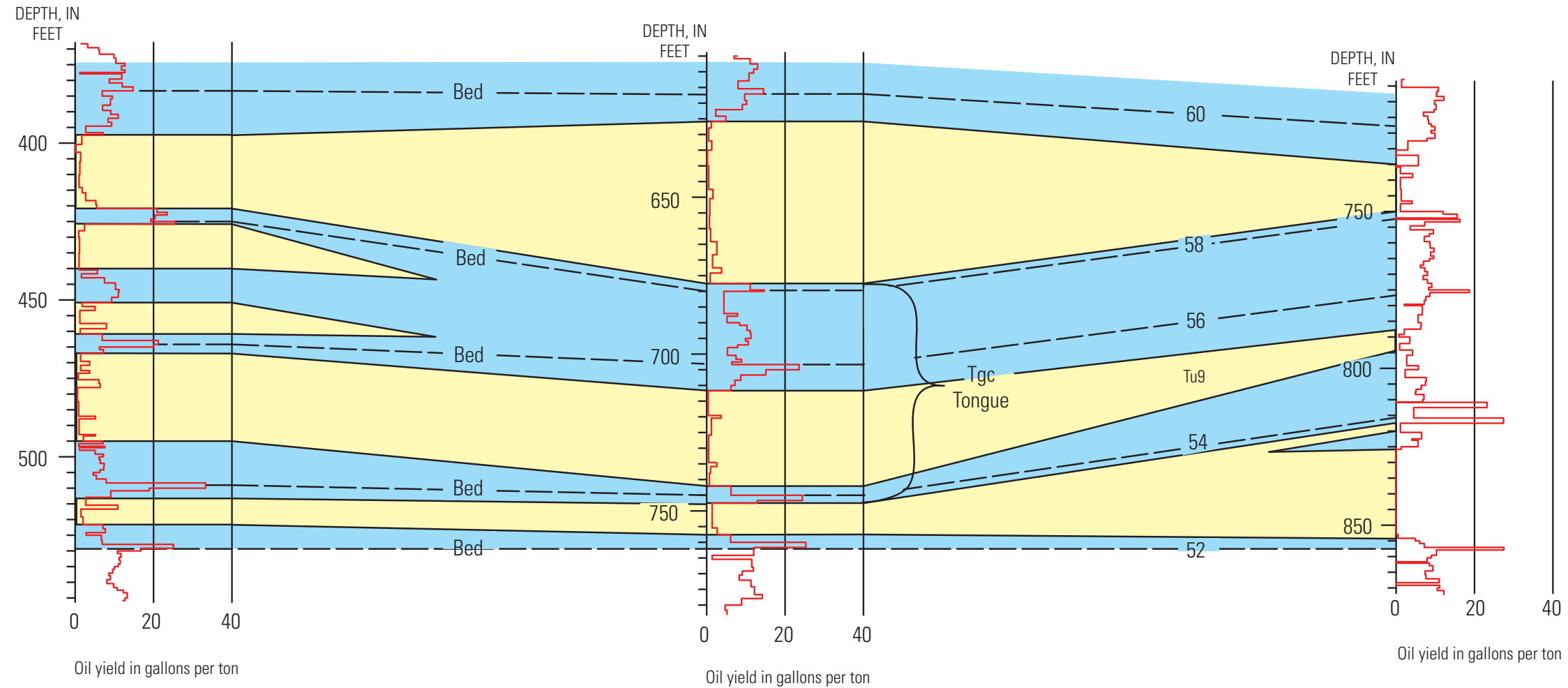

Figure 14. Cross section $G-G^{\prime}$ showing stratigraphic relation of tongue $\operatorname{Tgc}$ (table 1) of the Green River Formation (blue) with associated tongues of the Uinta Formation (yellow). The underlying Uinta tongue is labeled Tu9. Individual oil shale beds labeled 52-60. Location of section shown in figure 6. 


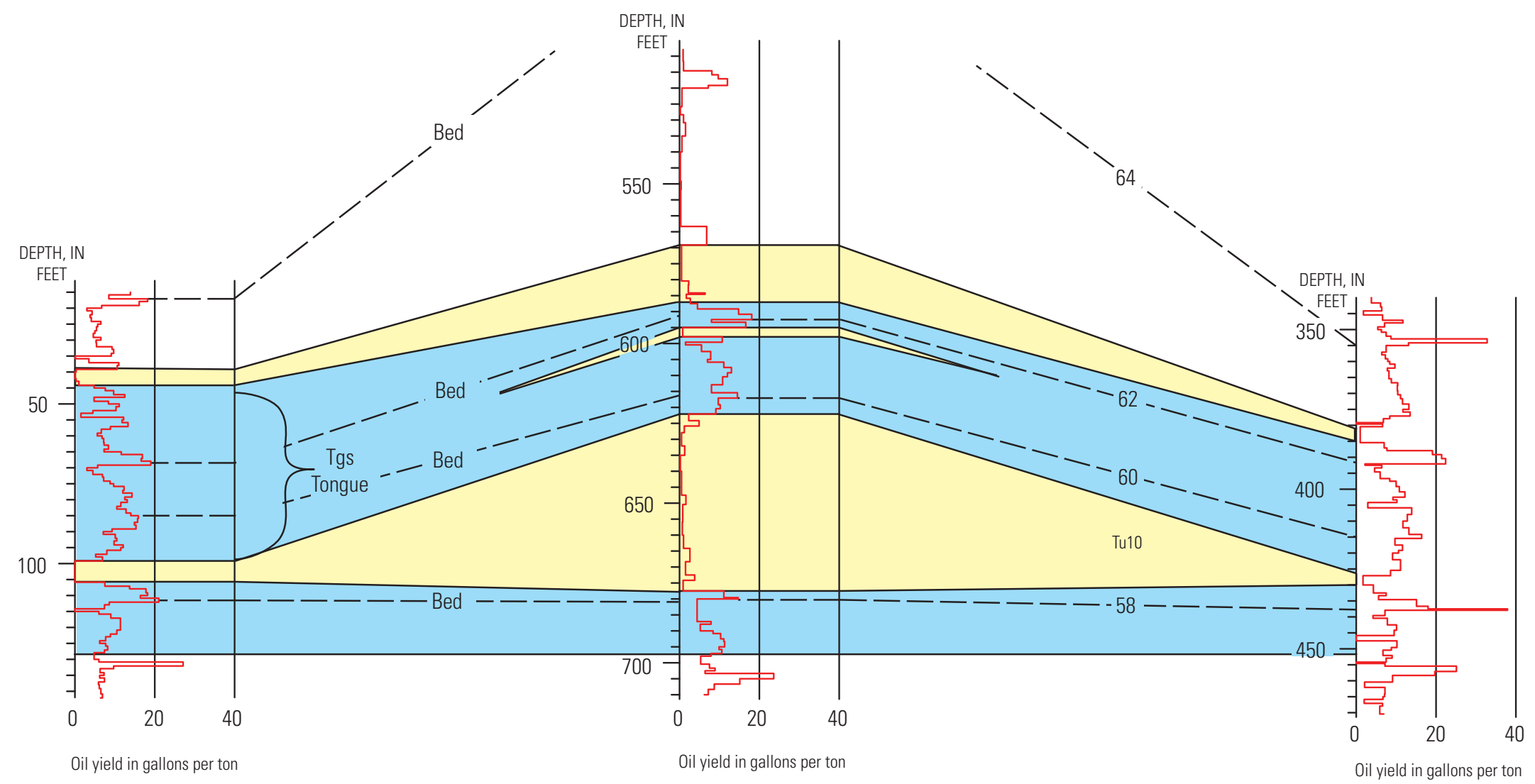


C111

Pacific Oil Co., Hardison 1

Sec. 2, T. 7 S., R. $98 \mathrm{~W}$.

DEPTH, IN

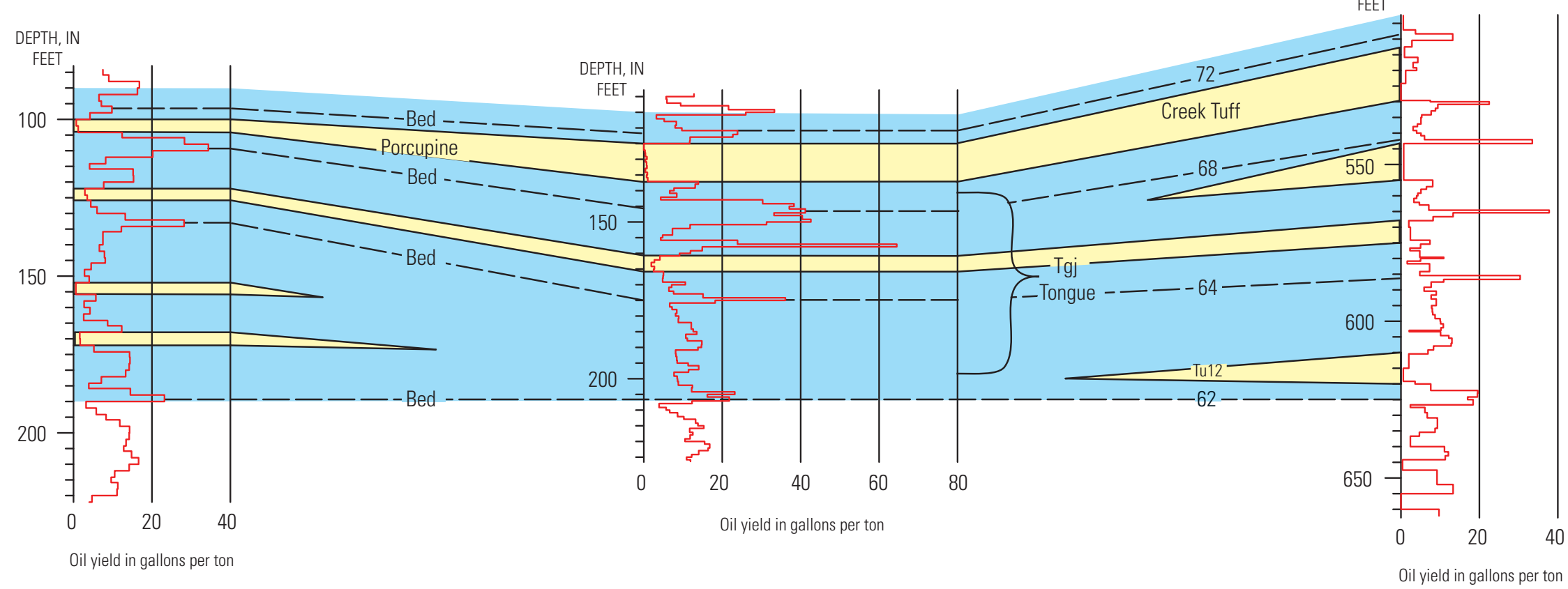

Figure 16. Cross section $I-I^{\prime}$ showing stratigraphic relation of tongue Tgj (table 1) of the Green River Formation (blue) with associated tongues of the Uinta 
Pacific Oil Co, Allen 1 Sec. 34, T. 6 S., R. 97 W.
US. Bureau of Land Management Triangulation Station Shale 2 Sec. 24, T. 7 S., R. 97 W.
Pure Oil Co, Battlement Mesa Core Hole Sec. 36, T. 7 S., R. 94 W.

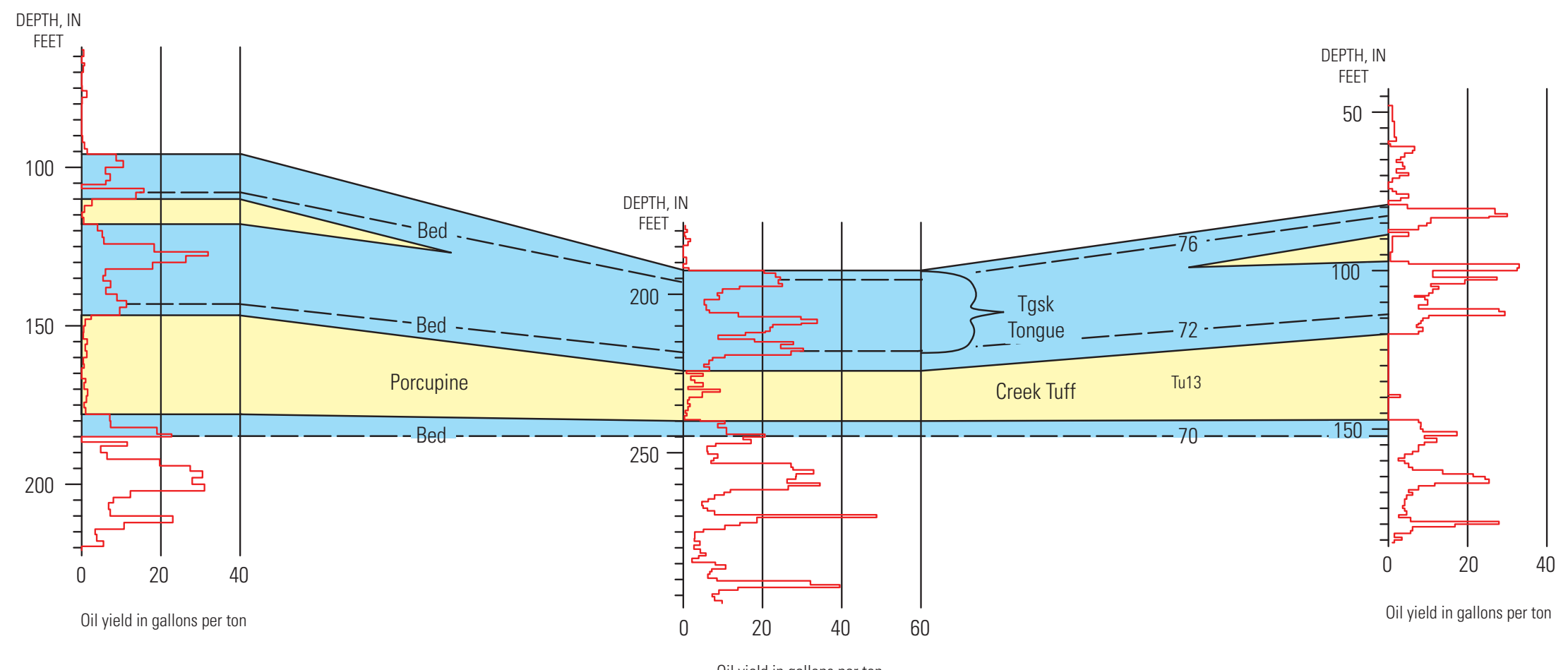

Oil yield in gallons per ton 


\section{Thirteenmile Creek Tongue}

The Thirteenmile Creek tongue (Tgt, fig. 4; cross section E-E', figs. 6 and 12) was named by Duncan and others (1974) from exposures on the north side of Dry Thirteenmile Creek in the SW1/4 sec. 26, SE1/4 sec. 27 and NW1/4 sec. 34, T. 2 S., R. 95 W. At the type locality, it is $137 \mathrm{ft}$ thick and consists mostly of marlstone and oil shale with a 25-ft light-brown sandstone near the top. Where the tongue joins the main body of the Green River Formation, it consists entirely of oil shale that includes three organic-rich beds 40, 42, and 44 (fig. 4) that have been named the "Big Three". Tongue Tgt has been mapped throughout most of the Greasewood Gulch quadrangle and in parts of the White River City, Barcus Creek SE, Barcus Creek, Wolf Ridge, Square S Ranch, Segar Mountain, No Name Ridge, Jessup Gulch, and Rock School quadrangles (fig. 5). It extends in the subsurface into the Bull Fork quadrangle and merges with the main body of the Green River Formation in the northeast corner of the No Name Ridge quadrangle and in the subsurface in the Jessup Gulch and Rock School quadrangles. Uinta tongue Tu7 consists of the sandstone beds that underlie and intertongue with the Thirteenmile Creek tongue (fig. 12).

\section{Black Sulphur Tongue}

The Black Sulphur tongue was named by Duncan and others (1974) from exposures along Black Sulphur Creek in $\mathrm{NW}^{1 / 4} \mathrm{SW}^{1} 1 / 4 \mathrm{SW}^{1 / 4}$ sec. 23, T. 2 S., R. 98 W., in the Rock School quadrangle (fig. 5). At the type locality, the tongue (labeled Tgb, fig. 4; cross section F-F', figs. 8 and 13) is 30 $\mathrm{ft}$ thick and consists mainly of gray and light-brown silty marlstone with a 6-ft siltstone bed $18 \mathrm{ft}$ below the top. In the area close to its join with the main body of the Green River Formation, it consists entirely of oil shale, including organicrich oil shale beds 48 through 52 (fig. 13). Where a sandstone bed separating oil shale bed 52 from bed 54 in some places is missing, bed 54 is mapped as the uppermost unit in tongue Tgb. The unit has been mapped in the Wolf Ridge, Square S Ranch, Jessup Gulch, Rock School, and Yankee Gulch quadrangles (fig. 5). Although not mapped, it extends into the Black Cabin Gulch quadrangle and may be traced in the subsurface into the McCarthy Gulch, Bull Fork, Jessup Gulch, and Figure Four Spring quadrangles (fig. 5). The tongue grades into the Uinta Formation in the Greasewood Gulch and Segar Mountain quadrangles and merges with the main body of the Green River Formation in the No Name Ridge quadrangle. Uinta tongue Tu8 includes the sandstone at the base of oil shale bed 48 and other intervening sandstones between bed 48 and bed 54 (fig. 4).

\section{Coughs Creek Tongue}

The Coughs Creek tongue was named by O'Sullivan (1975) from exposures along the west side of Cow Creek about a mile northwest of the junction of Coughs Creek with Cow Creek in the SW1/4SE $1 / 4$ sec. 12, T. 4 S., R. 95 W., in the Rio Blanco quadrangle (fig. 5). The tongue (Tgc, fig. 4; cross section $\mathrm{G}-\mathrm{G}^{\prime}$, figs. 6 and 14 ) at the type locality consists of an upper marlstone unit $23 \mathrm{ft}$ thick, a middle tan siltstone, sandstone, and gray marlstone unit $55 \mathrm{ft}$ thick, and a lower thin-bedded gray marlstone unit $30 \mathrm{ft}$ thick, with a 0.1 -ft-thick rich oil shale bed in the middle. In the area near the join of the tongue with the main body of the Green River Formation, it consists entirely of oil shale (beds 54 through 58, fig. 14). In some localities, the sandstone bed between beds 52 and 54 is thin or missing, in which case bed 54 has been mapped as part of the Black Sulphur tongue. The Coughs Creek tongue has been mapped throughout most of the Figure Four Spring, Cutoff Gulch, and McCarthy Gulch quadrangles and in parts of the Thirteen Mile Creek, No Name Ridge, Rio Blanco, Forked Gulch, Circle Dot Gulch, Mount Blaine, and Bull Fork quadrangles (fig. 5). Although not mapped, it probably extends into the Jessup Gulch, Razorback Ridge, Yankee Gulch, and Rock School quadrangles. The tongue merges with the main body of the Green River Formation in the Rio Blanco, Forked Gulch, Circle Dot Gulch, and Mount Blaine quadrangles and grades into the Uinta Formation in the No Name Ridge quadrangle and probably in the Jessup Gulch, Rock School, and Yankee Gulch quadrangles. Uinta tongue Tu9 includes the sandstone below bed 54 and all intervening sandstones between beds 54 and 58.

\section{Stewart Gulch Tongue}

The Stewart Gulch tongue of the Green River Formation (Tgs, fig. 4; cross section $\mathrm{H}-\mathrm{H}^{\prime}$, figs. 8 and 15) was named by Hail (1977) from exposures on the east side of the Middle Fork of Stewart Gulch in the SW1/3NE1/3NW1/4 sec. 3, T. 4 S., R. 96 W., in the Cutoff Gulch quadrangle. At the type locality, the tongue consists of an upper unit of $23 \mathrm{ft}$ of light-gray to light-brownish gray silty marlstone, with $1 \mathrm{ft}$ of light-brown oil shale near the middle, underlain by $10 \mathrm{ft}$ of light-brown sandstone, $13 \mathrm{ft}$ of greenish gray marly siltstone, and $4 \mathrm{ft}$ of light-brown silty marlstone. In the area near its join with the main body of the Green River Formation, the tongue consists mostly of oil shale, including beds 60 and 62 (figs. 4 and 15). It is present throughout the Bull Fork and Cutoff Gulch quadrangles, merges with the main body of the Green River Formation in the McCarthy Gulch, Forked Gulch, Circle Dot Gulch, Mount Blaine, and Figure Four Spring quadrangles, and, although not mapped, extends into and possibly grades into the Uinta Formation in the Razorback 
Ridge, Rock School, Jessup Gulch, and No Name Ridge quadrangles (fig. 5). The Tu10 tongue of the Uinta Formation includes the sandstone bed at the base of oil shale bed 60 and all other sandstone beds between beds 60 and 62 .

\section{Marlstone at Barnes Ridge and Marker Bed at Bull Fork}

The "Marlstone at Barnes Ridge" and "Marker Bed at Bull Fork" are generally exposed as white bands on ridges that cap the Roan Plateau and trend westward to Ts. 4 and $5 \mathrm{~S}$. Hail $(1975,1977)$ described the Barnes Ridge unit in the Cutoff Gulch quadrangle, and the Bull Fork unit in the Bull Fork quadrangle as consisting of gray to light-brown marlstone with thin beds of oil shale. No assays of the marlstones are available and the sandstone and siltstone beds underlying the units were not specifically identified, so no cross section was prepared for this report to illustrate their intertonguing relation with the Uinta Formation. Near the merger of these units with the main body of the Green River Formation, they consist almost entirely of oil shale (possibly beds 64 and 66, fig. 4).

The Barnes Ridge unit is mapped throughout much of the Cutoff Gulch and Bull Fork quadrangles and in the southeast quarter of the Figure Four Spring quadrangle (fig. 5). It has been mapped as Tgs1 in places along the northern boundary of the Mount Blaine quadrangle and as Tgj along the northern boundary of the Circle Dot Gulch quadrangle and the western boundary of the McCarthy Gulch quadrangle. The unit merges with the Stewart Gulch tongue (Tgs, fig. 4) in the southeast quarter of the Figure Four Spring quadrangle. The Bull Fork is mapped high on the ridges in the south half of the Bull Fork quadrangle. At places along the northern boundary of the Mount Blaine quadrangle it is also mapped as Tgsl.

\section{Marlstone at Sleepy Ridge and Marlstone at Jackrabbit Ridge}

The "Marlstone at Sleepy Ridge" was named by Hail (1978) from exposures on Sleepy Ridge in the Mount Blaine quadrangle (fig. 5). The approximate stratigraphic equivalent in the Circle Dot Gulch quadrangle was named the "Marlstone at Jackrabbit Ridge" by Hail (1992) from exposures on Jackrabbit Ridge. At the type locality, the Sleepy Ridge and the Jackrabbit Ridge units (Tgsl and Tgj, fig. 4; cross section I-I', figs. 6 and 16) both consist of light-gray marlstone, oil shale, siltstone, and sandstone. Near the area where they merge with the main body of the Green River Formation they are mainly oil shale (beds 64 through 70, fig. 4).

The "Marlstone at Sleepy Ridge" is mapped almost throughout the Mount Blaine quadrangle, as well as in the north half of the Desert Gulch quadrangle (fig. 5) where it merges with the main body of the Green River Formation. The "Marlstone at Jackrabbit Ridge" is mapped in the Circle Dot Gulch, McCarthy Gulch, Rio Blanco, Forked Gulch, and Anvil
Points quadrangles. It grades into the Uinta Formation in the southern part of the No Name Ridge quadrangle and merges with the main body of the Green River Formation in the middle of the Circle Dot Gulch quadrangle, the northern third of the Forked Gulch quadrangle and the northern half of the Anvil Points quadrangle; it may also be traced in the subsurface into the Red Pinnacle and Long Point quadrangles. The Tul2 tongue of the Uinta Formation includes the sandstone bed at the base of bed 64 and all other sandstone beds between 64 and 70 (fig. 4).

\section{Marlstone at Skinner Ridge}

The uppermost tongue of the Green River Formation in Colorado is the "Marlstone at Skinner Ridge", named by Hail (1978) for exposures on Skinner Ridge in the Mount Blaine quadrangle (fig. 5). At the type locality, the unit (Tgsk, fig. 4; cross section J-J', figs. 8 and 17) consists of light-gray marlstone and silty marlstone with some lean oil shale, and in places contains thin papery oil shale beds. It is separated from the marlstone at Sleepy Ridge by a tuff or tuffaceous sandstone bed informally named the "Porcupine Creek tuff" (Uinta tongue Tu13, fig. 4) from exposures in the drainage of Porcupine Creek in the North Mamm Peak quadrangle on the north flank of Battlement Mesa. This tuff bed is believed to be the stratigraphic equivalent of the Horse Bench Sandstone Bed in the eastern part of the Uinta Basin, Utah. In the area near where the Skinner Ridge merges with the main body of the Green River Formation it consists mainly of oil shale (beds 72 through 76, fig. 4). The "Marlstone at Skinner Ridge" has been mapped on the Mount Blaine and Desert Gulch quadrangles (fig. 5). It is probably present but not mapped on the Red Pinnacle, Long Point, The Saddle, Anvil Points, Rulison, North Mamm Peak, and Hawxhurst quadrangles. The Hawxhurst and North Mamm Peak quadrangles are adjacent to the Rulison quadrangle on the south and east and are not shown on fig. 5 .

At places in the Piceance Creek Basin there are oil shale beds that are stratigraphically higher than the beds in the marlstone at Skinner Ridge. They are in lenses of limited areal extent and were probably deposited in isolated ponds during late phases of Lake Uinta.

\section{Shale-0il Resources}

The shale-oil resource estimates by the U.S. Geological Survey-about 1 trillion barrels of oil contained in the Green River Formation in the Piceance Creek Basin —included resources from a series of seven rich oil shale zones and the intervening leaner zones (Pitman and others, 1989). These figures, however, do not include the sequence of moderately rich oil shale beds, between the "A Groove" and the top of the Big 3 (beds 2 through 44, fig. 4), commonly called the R-8 zone. The R-8 zone was estimated to contain a total of 128.5 billion barrels of oil based mostly on assay data from cores 
drilled prior to 1967 (Pitman and Donnell, 1973). The zone, in an area of about $400 \mathrm{mi}^{2}$ within Ts. 4, 5, and 6 S. and Rs. 95 to $98 \mathrm{~W}$., is free of clastic interbeds of the Uinta Formation. The zone in this area averages about $250 \mathrm{ft}$ in thickness, has an average value of 16 gallons of oil per ton of shale, and is estimated to contain an in-place resource of 73 billion barrels of oil. As noted by Pitman and Donnell (1973) the R-8 zone is richest in T. 5 S., R. 96 W., where it is $250 \mathrm{ft}$ thick and has an average yield of 19 gallons of oil per ton with a total in-place resource of 6.5 billion barrels.

Shale-oil resources published by Pitman and Donnell (1973) were reported in four separate units that may be equated in general to one or more combinations of the Green River tongues described in this report, as follows: Unit 1 is equivalent to tongues Tggc, Tgtc, and Tgm; Unit 2 is equivalent to tongue Tgy, and Units 3 and 4 are equivalent to tongues Tgd and Tgt.

\section{References}

Donnell, J.R., 1982, Preliminary geological map of the Sagebrush Hill Quadrangle, Rio Blanco County, Colorado: U.S. Geological Survey Miscellaneous Field Studies Map MF-1398, scale 1:24,000.

Duncan, D.C., Hail, W.J., O’Sullivan, R.B., and Pipiringos, G.N., 1974, Four newly named tongues of Eocene Green River Formation, Northern Piceance Creek basin, Colorado: U.S. Geological Survey Bulletin 1394-F, 13 p. F1-F13.

Franczyk, K.J., Fouch, T.D., Johnson, R.C., Molenaar, C.M., and Cobban, W.C., 1992, Cretaceous and Tertiary paleographic reconstructions for the Uinta-Piceance basin study area Colorado and Utah: U.S. Geological Survey Bulletin 1787-Q, 37 p.

Hail, W.J., Jr., 1975, Preliminary geologic map of the Cutoff Gulch Quadrangle, Rio Blanco and Garfield counties, Colorado: U.S. Geological Survey Miscellaneous Field Studies Map MF-691, scale 1:24,000.

Hail, W.J., Jr., 1977, Stewart Gulch Tongue-A new tongue of the Eocene Green River Formation, Piceance Creek Basin, Colorado: U.S. Geological Survey Bulletin 1422-E, 8 p.

Hail, W.J., Jr., 1978, Preliminary geologic map of the Mount Blaine Quadrangle, Garfield County, Colorado: U.S. Geological Survey Miscellaneous Field Studies Map MF-984, scale 1:24,000.
Hail, W.J., Jr., 1984, Geologic Map of the Barcus Creek Quadrangle, Rio Blanco County, Colorado: U.S. Geological Survey Geologic Quadrangle Map GQ-1578, scale 1:24,000.

Hail, W.J., Jr., 1987, Chart showing intertongued units of the Eocene Green River and Uinta Formations, northwestern Piceance Creek Basin, northwestern Colorado: U.S. Geological Survey Miscellaneous Series Map I-1797-B.

Hail, W.J., Jr., 1990, Geology of the Lower Yellow Creek area, northwestern Colorado: U.S. Geological Survey Bulletin 1787-O, 45 p.

Hail, W.J., Jr., 1992, Geology of the Central Roan Plateau area northwestern Colorado: U.S. Geological Survey Bulletin 1787-R, 26 p., 2 pls.

O'Sullivan, R.B., 1974, Chart showing correlation of selected units of the Eocene Uinta and Green River Formations, eastcentral Piceance Creek basin, northwestern Colorado: U.S. Geological Survey Oil and Gas Investigations Chart OC-67.

O’Sullivan, R.B. 1975, Coughs Creek Tongue-A new tongue of the Eocene Green River Formation, Piceance Creek basin, Colorado: U.S. Geological Survey Bulletin 1395-G, $7 \mathrm{p}$.

O’Sullivan, R.B., 1987, Chart showing correlation of selected parts of the Eocene Uinta and Green River Formations, southeastern Piceance Creek basin, Colorado: U.S. Geological Survey Field Studies Map MF-1986.

Pitman, J. K., and Donnell, J. R., 1973, Potential shale-oil resources of a stratigraphic sequence above the Mahogany Zone, Green River Formation, Piceance Creek Basin, Colorado: U.S. Geological Survey Journal of Research, 1, no. 4 , p. 467-473.

Pitman, J. K. and Johnson, R. C., 1978, Isopach, structure contour and resource maps of the Mahogany oil-shale zone, Green River Formation, Piceance Creek basin, Colorado: U.S. Geological Survey Field Studies Map MF-958, scale $1: 126,720$.

Pitman, J. K., Pierce, F. W., and Grundy, W. D., 1989, Thickness, oil yield, and kriged resource estimates for the Eocene Green River Formation, Piceance Creek Basin, Colorado: U.S. Geological Survey Oil and Gas Investigations Chart OC-132. 
Table 2. List of drill holes shown on cross sections

\begin{tabular}{|c|c|}
\hline Well Name & Location \\
\hline U31 Skyline Oil Co., Watson 1 & Sec. 5, T. 11 S., R. 25 E. \\
\hline C20 Tell Ertl Jan & Sec. 18 , T. 2 S., R. 99 W. \\
\hline C34 U.S. Bur. of Mines/AEC, Colorado 1 & Sec. 13 , T. 1 N., R. 98 W. \\
\hline C35 U.S. Bureau of Mines/AEC, Colorado 2 & Sec. 14, T. 1 S., R. 99 W. \\
\hline C37 U.S. Bureau of Land Management, Triangulation Station Shale 2 & Sec. 24, T. 7 S., R. 97 W. \\
\hline C47 Union Oil Company, Florence & Sec. 31, T. 4 S., R. 95 W. \\
\hline C104 Gallagher - Victor, Gallagher & Sec. 13 , T. 6 S., R. 100 W. \\
\hline C109 Pacific Oil Co., Allen 1 & Sec. 34, T. 6 S., R. 97 W. \\
\hline C111 Pacific Oil Co., Hardison 1 & Sec. 2, T. 7 S., R. 98 W. \\
\hline C124 Savage Oil Shale Development Corp., Hunter & Sec. 23, T. 4 S., R. 98 W. \\
\hline C126 Savage Oil Shale Development Corp., Camp & Sec. 35, T. 4 S., R. 98 W. \\
\hline C139 Getty Oil Co., 01-23/D & Sec. 23, T. 5 S., R. 98 W. \\
\hline C149 Mobil Oil Co., [Born] E (Core Hole 5) & Sec. 11, T. 6 S., R. 96 W. \\
\hline C150 Mobil Oil Co., [Born] F (Core Hole 6) & Sec. 11, T. 6 S., R. 96 W. \\
\hline C151 Marathon Oil Co., Square S No. 1 & Sec. 4, T. 2 S., R. 97 W. \\
\hline C172 Shell Oil Co. $23 X-10$ & Sec. 10, T. 7 S., R. 97 W. \\
\hline C183 Pure Oil Co., Battlement Mesa Core Hole & Sec. 36, T. 7 S., R. 94 W. \\
\hline C195 ARCO-Mobil-Equity, Figure Four 31-1 & Sec. 31, T. 3 S., R. 98 W. \\
\hline C254 ARCO(C-b Project), Sorghum Gulch 11 & Sec. 7, T. 3 S., R. 96 W. \\
\hline C262 Gulf/Std. Ind. (Ca Project) Ch 2-3 & Sec. 33, T. 1 S., R. 99 W. \\
\hline C272 Rio Blanco Oil Shale Co., C-14 & Sec. 10, T. 2 S., R. 99 W. \\
\hline C309 Shell Oil (Ertl Claims), 32-7 & Sec. 7, T. 2 S., R. 99 W. \\
\hline C310 Shell Oil (Ertl Claims), 42X-10 & Sec. 10, T. 2 S., R. 100W. \\
\hline C329 Carter Oil Co., Opportunity2 & Sec. 28, T. 1 N., R. 96 W. \\
\hline C330 Carter Oil Co., Square S No. 1 & Sec. 21, T. 1 S., R. 97 W. \\
\hline C333 Getty Oil Co., 32-27 & Sec. 27, T. 5 S., R. 97 W. \\
\hline C350 U.S. Navy, Core Hole 15/16 (NOSR I) & Sec. 1, T. 5 S., R. 95 W. \\
\hline C508 Phillips Petroleum Co., P-02 & Sec. 23, T. 1 S., R. 100 W. \\
\hline C517 Phillips Petroleum Co., P-19 & Sec. 36, T. 1 S., R. 100 W. \\
\hline C518 Phillips Petroleum Co., P-20 & Sec. 26, T. 1 S., R. $100 \mathrm{~W}$. \\
\hline
\end{tabular}


Publishing support provided by:

Denver Publishing Service Center

For more information concerning this publication, contact:

Team Chief Scientist, USGS Central Energy Resources

Box 25046, Mail Stop 939

Denver, CO 80225

(303) 236-1647

Or visit the Central Energy Resources Team site at:

http://energy.cr.usgs.gov/ 


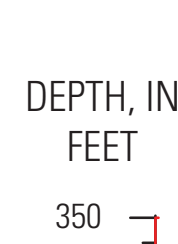
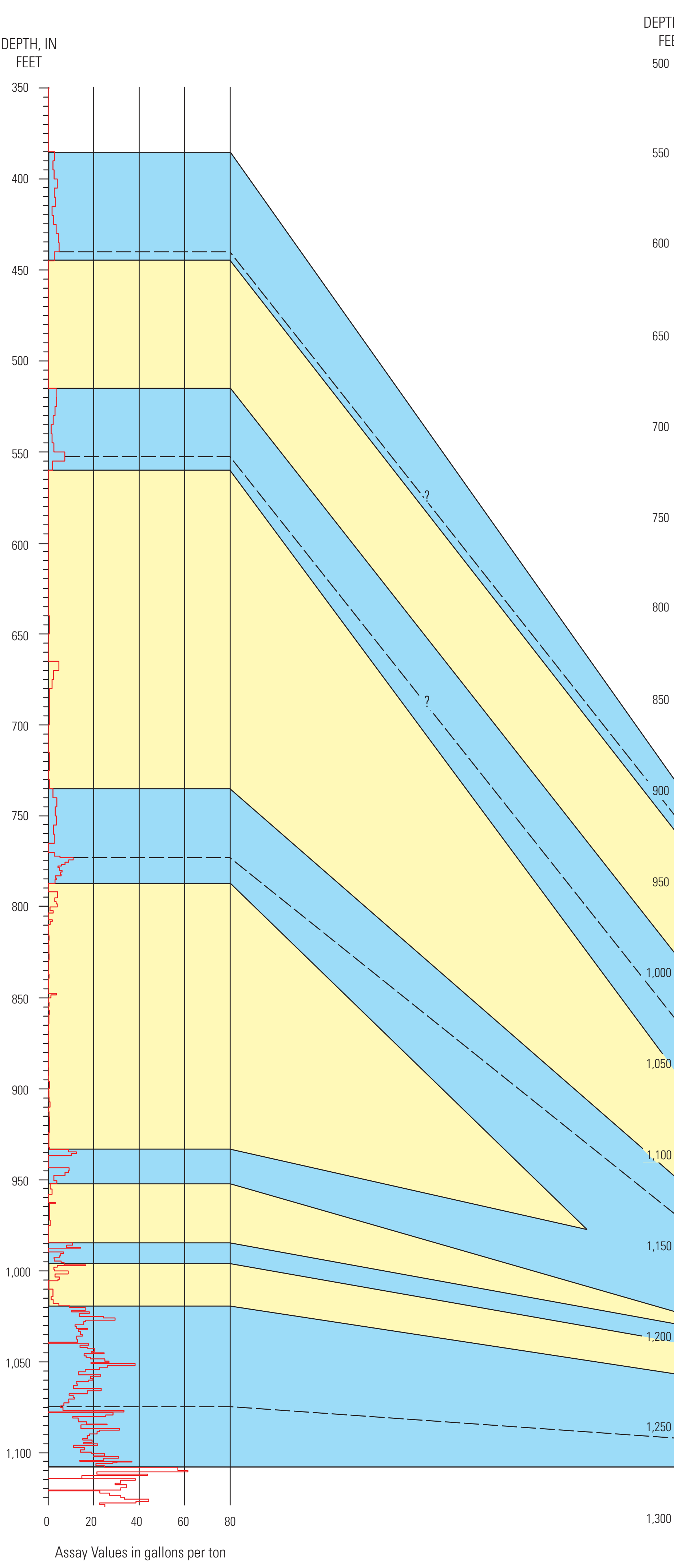

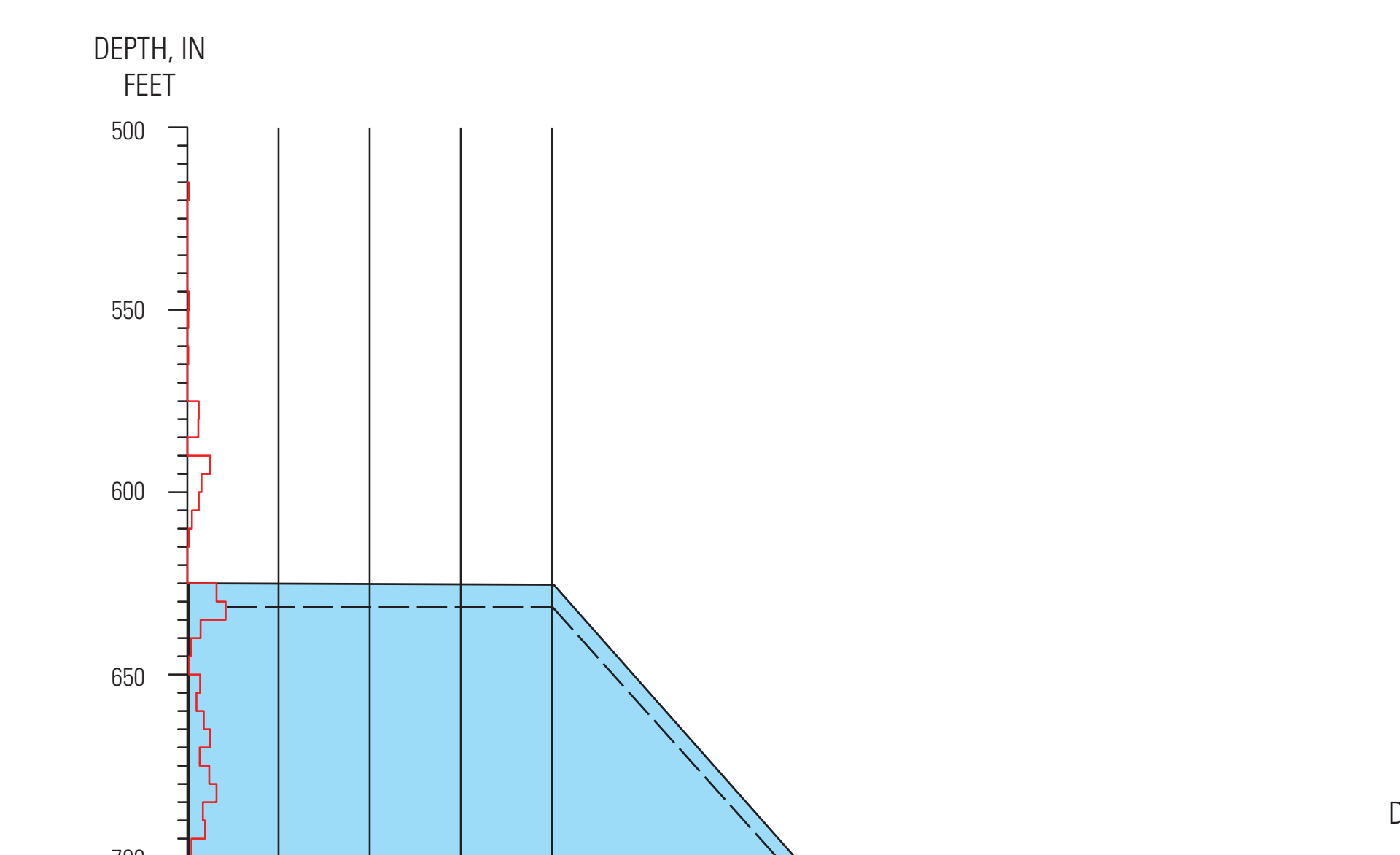

FEFTi

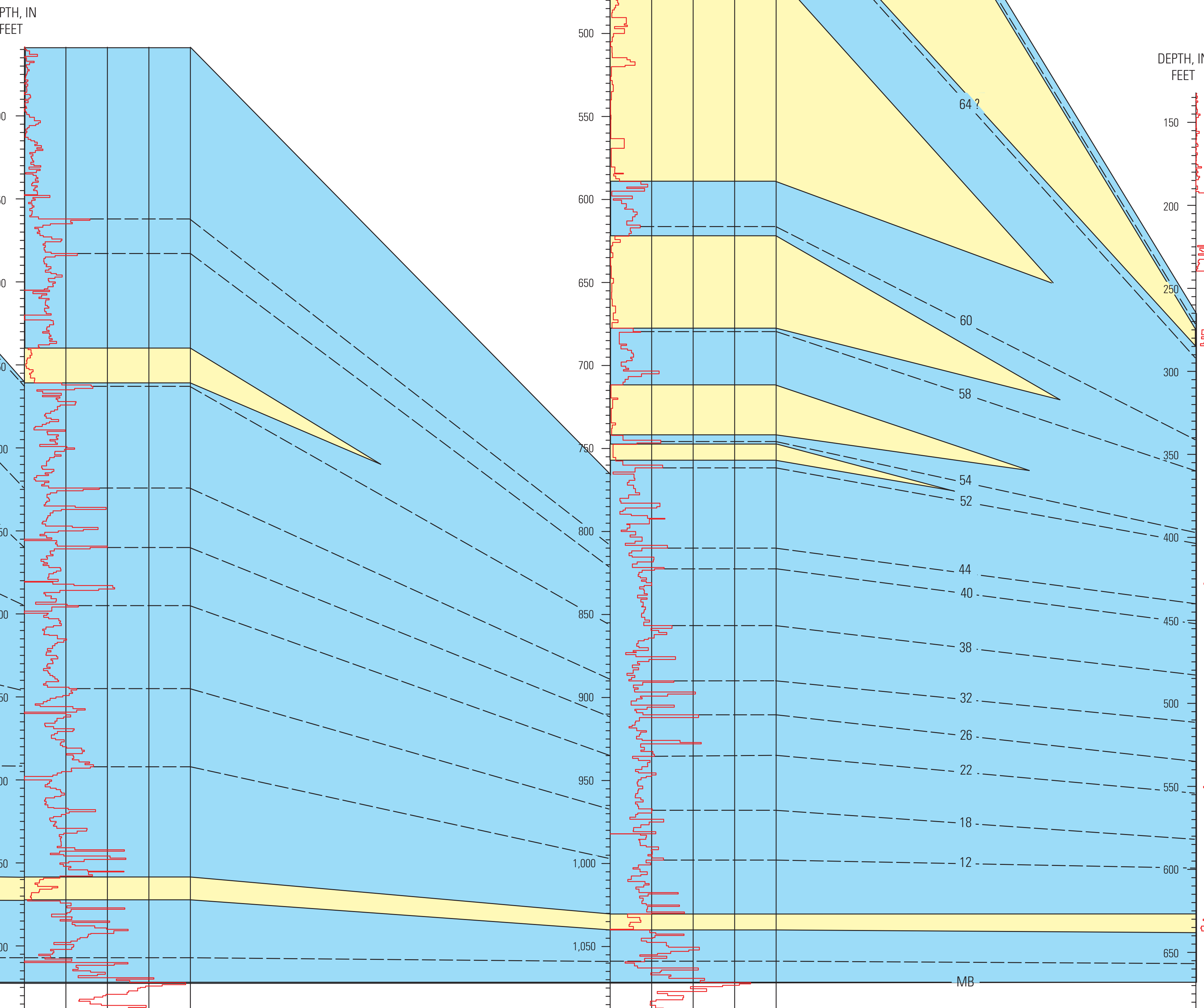

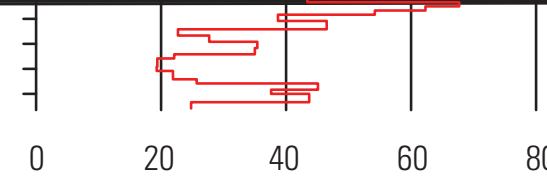

(1)

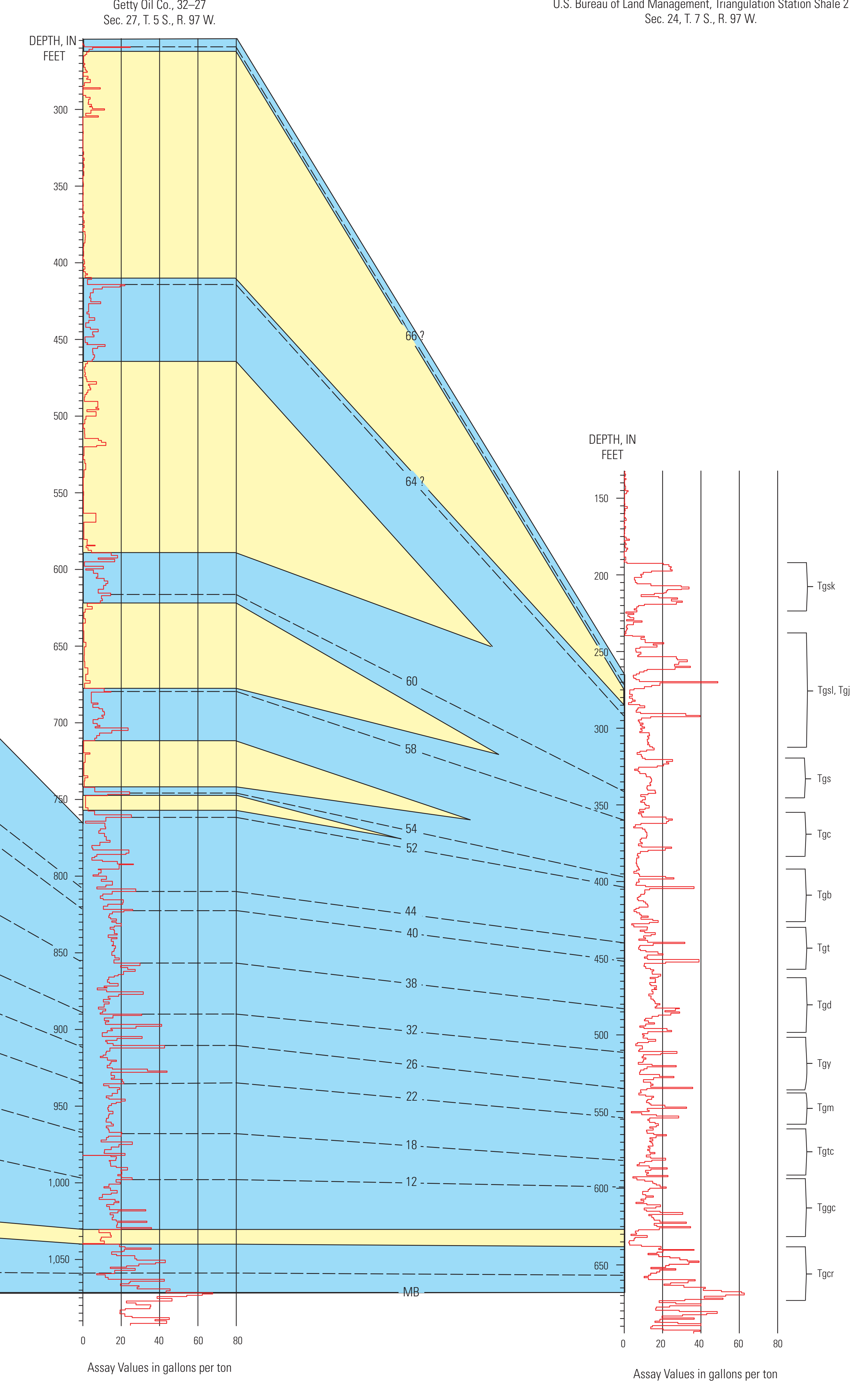


